\title{
Движение рабочей силы и рабочих мест на российском рынке труда: факты, тенденции, перспективы
}

Информационный бюллетень

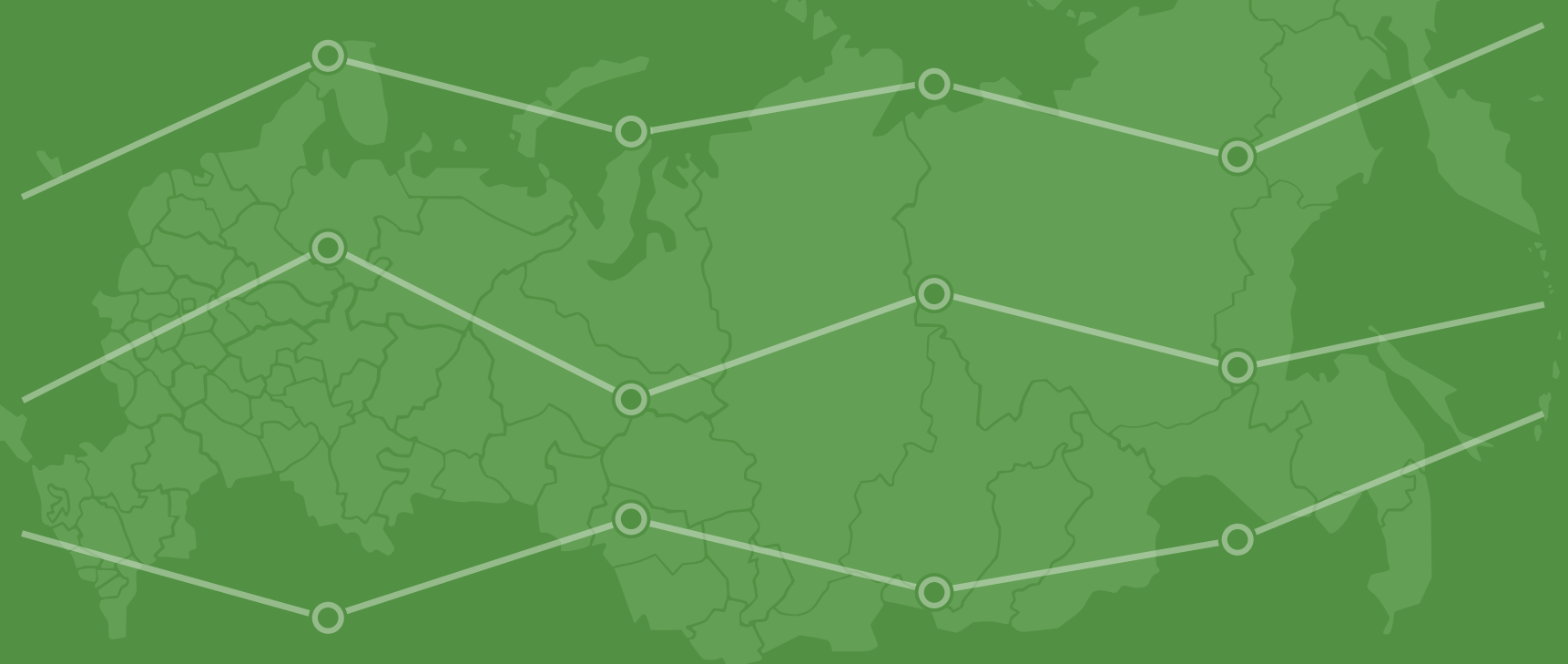




\section{Движение рабочей силы и рабочих мест на российском рынке труда: факты, тенденции, перспективы}

Информационный бюллетень 
УДК 331.554

ББК 65.240

C50

Научные редакторы - С.Ю. Рощин, Л.И. Смирных

\section{Смирных, Л. И., Емелина, Н.}

с50 Движение рабочей силы и рабочих мест на российском рынке труда: факты, тенденции, перспективы : информационный бюллетень [Электронный ресурс] / Л. И. Смирных, Н. Емелина ; под науч. ред. С. Ю. Рощина, Л. И. Смирных ; Нац. исслед. ун-т «Высшая школа экономики». - Электрон. текст. дан. (1,5 Мб). - М. : Изд. дом Высшей школы экономики, 2021. — ISBN 978-5-7598-2284-4.

Информационный бюллетень посвящен оценке движения рабочей силы и рабочих мест на российском рынке труда в 2009-2020 гг. Для анализа были использованы агрегированные данные Федеральной службы государственной статистики для средних и крупных предприятий и дезагрегированные данные общероссийской базы вакансий «Работа в России» для малых, средних и крупных предприятий. Аналитическая часть информационного бюллетеня содержит результаты анализа таких показателей, как создание и ликвидация рабочих мест, наем и увольнения работников, а также соотношение между перераспределением рабочей силы и рабочих мест на российском рынке труда в период до и во время пандемии коронавируса (март - август 2020 г.). В результатах анализа учтена также разнородность российского рынка по отраслям и регионам.

УДК 331.554

ББК 65.240

doi:10.17323/978-5-7598-2284-4 ISBN 978-5-7598-2284-4 (c) Национальный исследовательский университет «Высшая школа экономики», 2021 


\section{Содержание}

Введение

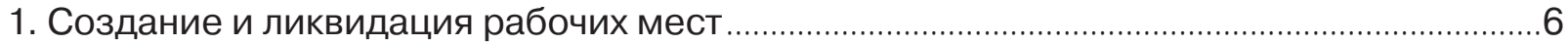

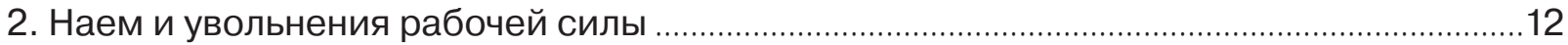

3. Соотношение между перераспределениями рабочей силы и рабочих мест

4. Движение рабочей силы и рабочих мест в период пандемии коронавируса. 25

Заключение 34

Список литературы 39

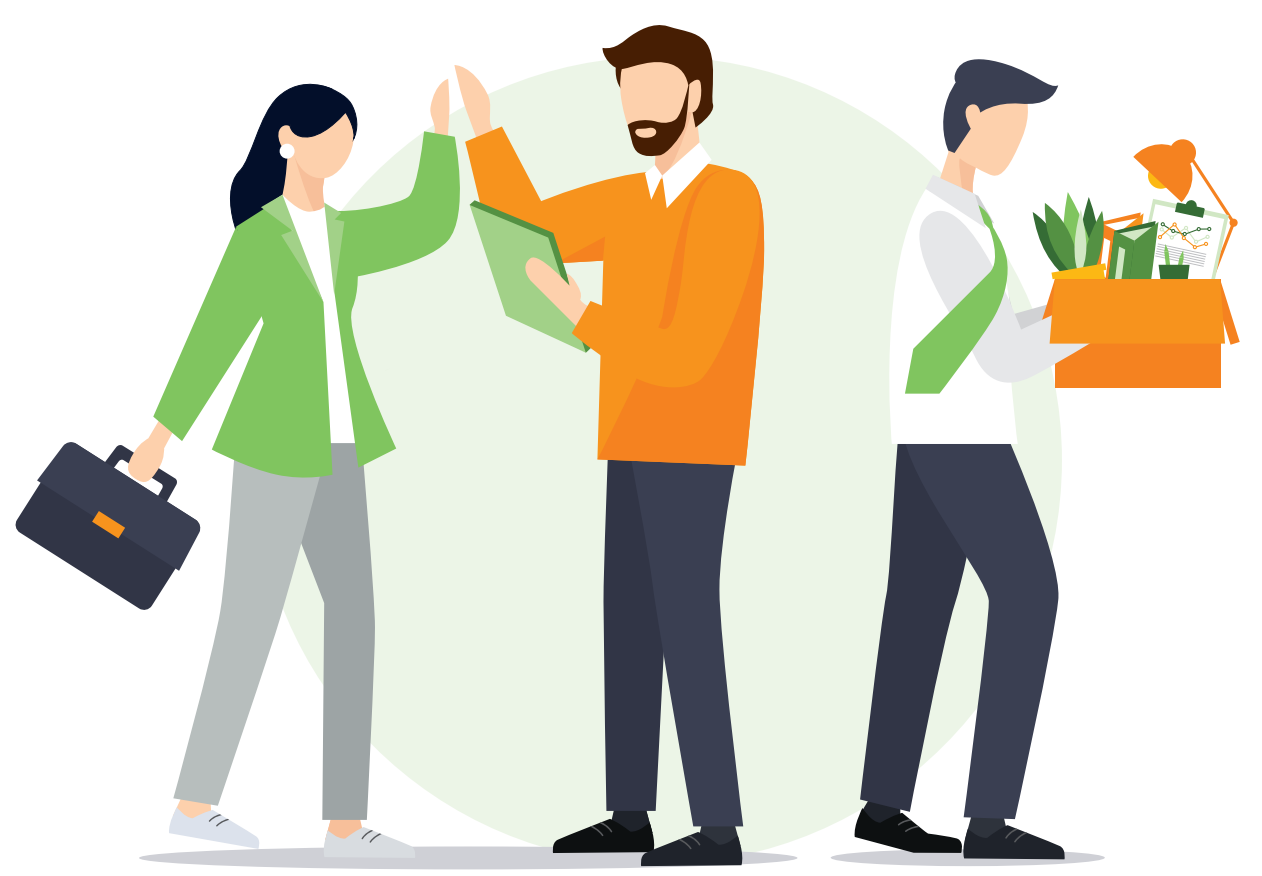




\section{Введение}

В 2009-2020 гг. в российской экономике произошли значительные изменения. Страна испытала воздействие экономических санкций, усилились цифровые трансформации, в 2020 г. экономика столкнулась с пандемией коронавируса. Эти процессы отразились на функционировании российского рынка труда, в частности, на такой важной его составляющей, как движение рабочей силы и рабочих мест.

В любой экономике происходят наем и увольнения работников, создаются и ликвидируются рабочие места, осуществляется перераспределение рабочих мест и работников между регионами, отраслями, предприятиями, что оказывает влияние на эффективность использования трудовых ресурсов. Благодаря движению рабочей силы достигается более точное и качественное соответствие между характеристиками рабочей силы и рабочих мест. За счет повышения трудовой мобильности и создания рабочих мест может происходить рост занятости населения. В связи с этим оценка движения рабочей силы и рабочих мест имеет значение для разработки управленческих решений по регулированию рынка труда и мер по повышению уровня занятости.

Полученные ранее сведения о движении рабочей силы и рабочих мест позволяют судить о ситуации на рынке труда до 2012 г. [Гимпельсон, Жихарева, Капелюшников, 2014; Семеньков, 2014], описывают положение в отдельных регионах России [Лаврентьева, Патракова, 2017; Савельева, Сурцева, 2017]. С учетом динамичности происходящих изменений и трансформаций на рынке труда в данном исследовании представлены новые факты, сложившиеся тренды движения рабочей силы и рабочих мест за более длительный период (2009-2020 гг.). На их основе формулируются прогнозы на ближайшее будущее.

Исследование было выполнено на агрегированных данных Росстата для средних и крупных предприятий, а также с использованием дезагрегированных данных общероссийской базы вакансий «Работа в России», которые охватывают малые, средние и крупные предприятия (https://trudvsem.ru/).

Направления анализа формировались с учетом разнородности российского рынка труда. Российская Федерация неоднородна по уровню регионального развития, как 
следствие, положение населения и уровень занятости на региональных рынках труда могут существенно различаться. Наблюдается и отраслевая неоднородность. Одни отрасли экономики имеют высокую волатильность, другие являются более стабильными относительно экономической конъюнктуры. Есть растущие и сокращающиеся отрасли, отрасли с высокой долей труда, а также с высоким уровнем технической вооруженности. Учитывалось также, что крупные и средние предприятия являются хотя и значительным, но не единственным сегментом российской экономики. Активное развитие торговли и сферы услуг способствует увеличению числа малых предприятий с относительно коротким жизненным циклом, более гибких и динамичных по сравнению со средними и крупными предприятиями.

Движение рабочей силы и рабочих мест рассчитывалось как для страны в целом, так и отдельно по регионам и отраслям экономики. Особое внимание было уделено движению рабочей силы в период пандемии коронавируса (март - август 2000 г.). Исходя из этого, информационный бюллетень построен следующим образом. Первый раздел посвящен анализу движения рабочих мест на российском рынке труда. Во втором разделе проводится анализ найма и увольнений работников с учетом их добровольного и вынужденного характера. В третьем разделе рассматривается соотношение между перераспределением рабочей силы и рабочих мест, анализируется холостой оборот рабочей силы на российском рынке труда. Четвертый раздел характеризует движение рабочей силы и рабочих мест в период пандемии коронавируса. 


\section{1. Создание и ликвидация рабочих мест}

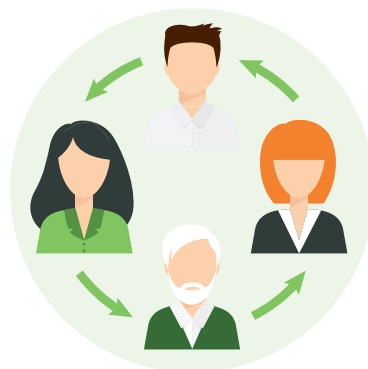

В 2019 г.

валовой оборот

рабочих мест

уменьшился почти

в 2 раза

по сравнению

с 2009 г.

Любые структурные изменения в экономике сопровождаются созданием и ликвидацией рабочих мест. Как правило, менее производительные и технологически устаревшие рабочие места замещаются на более современные и производительные. Со временем рождаются новые предприятия, а старые предприятия умирают, что оказывает влияние на общее число рабочих мест в экономике. Оценка создания и ликвидации рабочих мест была выполнена по методологии, которая широко применяется экономистами [Davis, Haltiwanger, 1999]'.

Полученные результаты свидетельствуют о том, что на протяжении 2009-2016 гг. ликвидация рабочих мест на предприятиях России опережала их создание. В 2017 г. оба показателя практически сравнялись, а в 2018-2019 гг. предприятия больше создавали рабочих мест, чем ликвидировали (рис. 1).

Однако наметившиеся позитивные изменения в создании рабочих мест являются недостаточным свидетельством оживления экономики. Дело в том, что в течение 2009-2019 гг. произошло постепенное сокращение валового оборота рабочих мест, которое выразилось в сокращении создаваемых и ликвидируемых рабочих мест. Валовой оборот рабочих мест уменьшился в 2019 г. почти в 2 раза по сравнению с 2009 г. Если в 2009 г. коэффициент создания рабочих мест был равен 8,2\%, то в 2019 г. он снизился до 5,8\%. В 2009 г. коэффициент ликвидации рабочих мест равнялся 12,6\%, а в 2019 г. он уменьшился практически

${ }^{1}$ Определения основных понятий, которые используются в рамках применяемой методологии, приводятся во вставках. 


\section{Основные понятия}

Рабочее место или работа - заполненная работником позиция для выполнения договора, заключаемого в явной или неявной форме между конкретным лицом и институциональной единицей на выполнение определенной работы за оговоренную плату в течение установленного срока или до дальнейшего уведомления.

Число созданных рабочих мест определяется по вновь созданным организациям (по средней численности работников) и организациям, численность работников на которых увеличилась (разница между средней численностью работников за январь - декабрь отчетного и средней численностью работников за январь - декабрь предыдущего года).

Число ликвидированных рабочих мест определяется по ликвидированным организациям (по средней численности работников) и организациям, численность работников на которых уменьшилась (разница между средней численностью работников за январь - декабрь отчетного и средней численностью работников за январь - декабрь предыдущего года).

Коэффициент создания рабочих мест рассчитывается делением числа созданных рабочих мест на среднее число замещенных рабочих мест в течение года.

Коэффициент ликвидации рабочих мест рассчитывается делением числа ликвидированных рабочих мест на среднее число замещенных рабочих мест в течение года.

Сальдо движения рабочих мест - разница между коэффициентами создания и ликвидации рабочих мест. Если значения сальдо отрицательные, то в экономике масштабы ликвидации рабочих мест превышают масштабы создания рабочих мест. И наоборот, если значения сальдо положительные, то в экономике создается больше рабочих мест, чем ликвидируется.

Коэффициент рождаемости организаций - отношение количества зарегистрированных организаций за отчетный период к среднему количеству организаций, учтенных органами государственной статистики в Статистическом регистре по данным государственной регистрации в отчетном периоде, рассчитанное на 1000 организаций.

Коэффициент официальной ликвидации организаций - отношение количества официально ликвидированных организаций за отчетный период к среднему количеству организаций, учтенных органами государственной статистики в Статистическом регистре по данным государственной регистрации в отчетном периоде, рассчитанное на 1000 организаций.

Источник: [Гимпельсон и др., 2012]. 


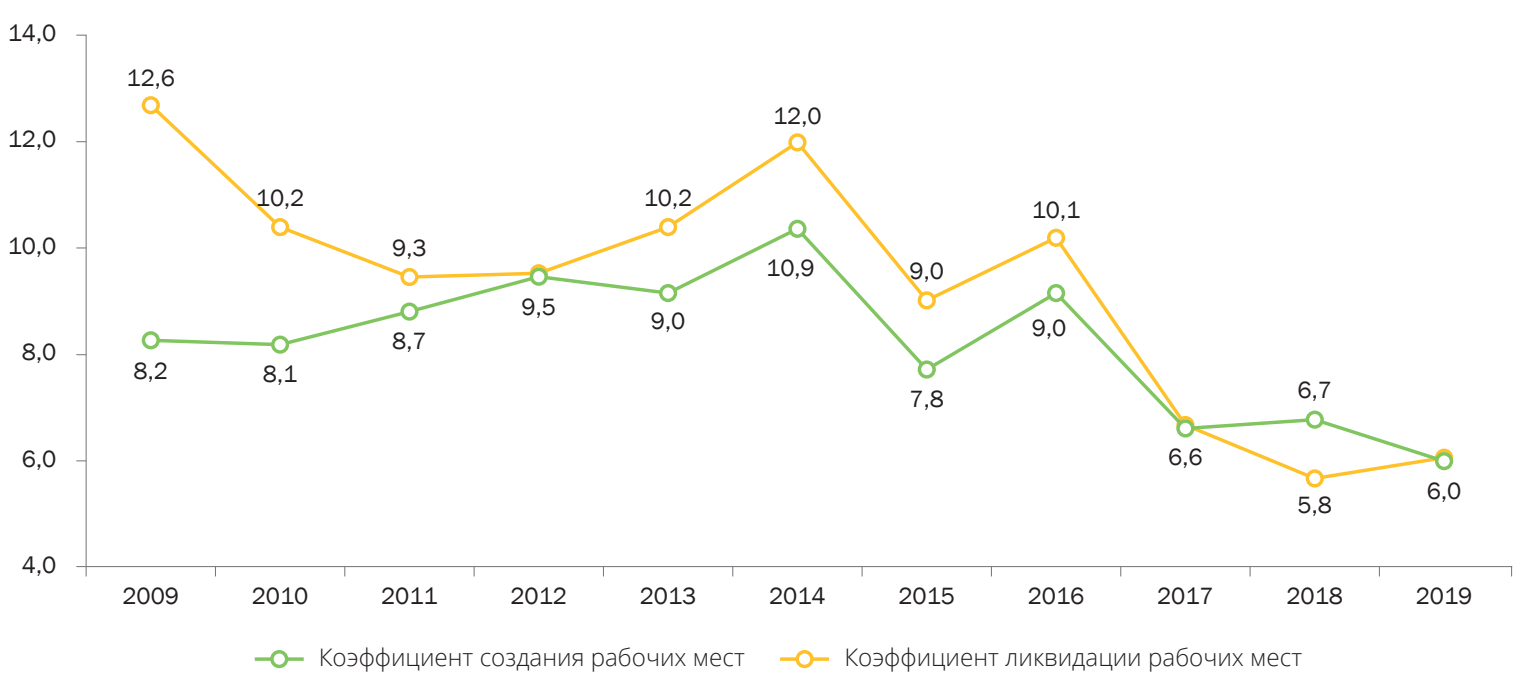

Рис. 1. Движение рабочих мест в 2009-2019 гг., \% Источник: Агрегированные данные Pосстата по трудовым ресурсам, 2020 г.

в 2 раза - до 6\%. Наиболее существенные снижения коэффициентов создания и ликвидации рабочих мест произошли после 2014 г. - с введением против России первых экономических санкций (рис. 1).

Провал 2014-2015 гг. сменился восстановлением в 2016 г., когда предприятия создавали и ликвидировали рабочие места уже на уровне 2013 г. Однако в 2017 г. коэффициенты создания и ликвидации рабочих мест вновь упали практически на треть по сравнению с 2016 г. Их дальнейшее снижение продолжилось до 2019 г. (рис. 1). В 2019 г. предприятия ликвидировали рабочих мест почти в 2 раза меньше, чем в кризисный 2009 г. Однако в этом же году они и создавали рабочих мест меньше, чем в кризисный 2009 г. (рис. 1).

Постепенное падение валового оборота рабочих мест происходило на фоне общего ухудшения экономической ситуации, отрицательной динамики основных макроэкономических показателей и стало свидетельством снижения темпов экономического роста, замедления реструктуризации и нарастания стагнации экономики.

При этом ситуация не была одинаково драматичной во всех отраслях экономики. Составы отраслей-лидеров и отраслей-аутсайдеров по созданию рабочих мест оставались все годы практически неизменными. В 2019 г. минимальное число создаваемых рабочих мест отмечалось в образовании и здравоохранении, как это было зафиксировано ранее [Гимпельсон, Жихарева, Капелюшников, 2014] (рис. 2). Наибольшее число рабочих мест создавалось в 2019 г. на предприятиях строительства, в сфере финансов и страхования, в бизнес-услугах. Эти отрасли во многом компенсировали сокращение рабочих мест в других отраслях экономики.

Индикатором сокращения рабочих мест в отрасли является превышение ликвидации рабочих мест над их созданием. В 2009-2019 гг. во многих отраслях экономики коэффициенты ликвидации рабочих мест были значительно выше коэффициентов их 


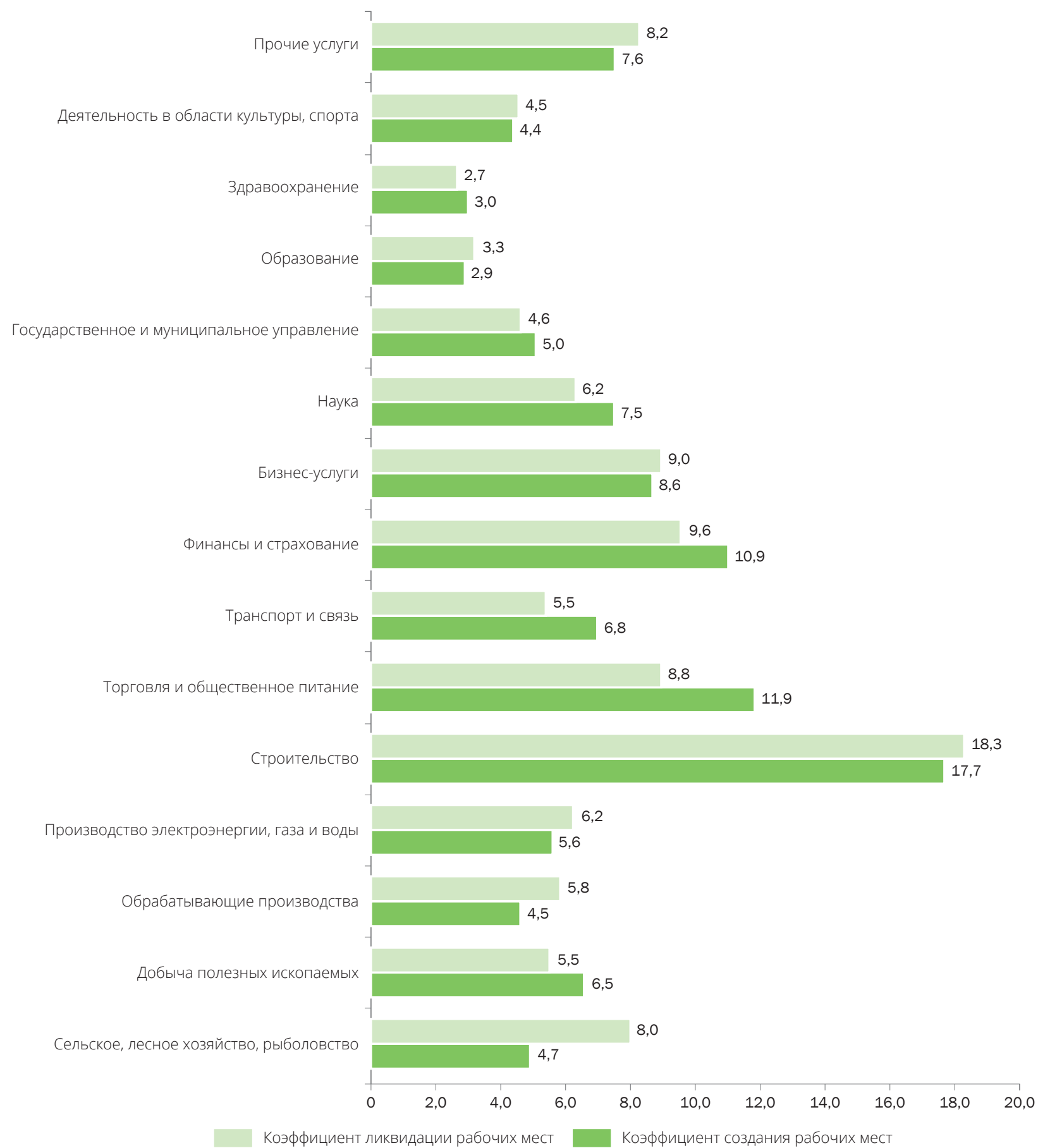

Рис. 2. Движение рабочих мест по видам экономической деятельности в 2019 г., \% Источник: Агрегированные данные Росстата по трудовым ресурсам, 2020 г.

создания, что приводило к формированию отрицательного сальдо движения рабочих мест. В 2019 г. максимальное превышение ликвидации рабочих мест над их созданием сложилось в обрабатывающих производствах, сельском и лесном хозяйстве.

В этом же году в некоторых отраслях экономики наблюдалось положительное сальдо, т.е. в них коэффициенты создания рабочих мест были выше коэффициентов их 
ликвидации. К таким отраслям относились, например, торговля и общественное питание, добыча полезных ископаемых, финансы и страхование, наука, транспорт и связь (рис. 2). Таким образом, одни отрасли экономики развивались, увеличивая количество рабочих мест, а другие сокращались, ликвидируя все больше рабочих мест.

Вклад в сокращение рабочих мест на рынке труда вносила ликвидация предприятий. В 2009-2019 гг. число предприятий в России уменьшилось с 4771,9 тыс. в 2009 г. до 4008,5 тыс. в 2019 г. Наибольшее сокращение количества предприятий произошло в сельском и лесном хозяйстве. За 10 лет доля предприятий в этой отрасли сократилась с 4,4\% в 2009 г. до 2,7\% в 2019 г. При этом практически вдвое увеличилась доля предприятий в отрасли производства и распределения электроэнергии, газа и воды с 0,6\% в 2009 г. до 1,2\% в 2019 г.

Сокращение количества предприятий происходило неравномерно по регионам России. В 2009-2019гг. значительное сокращение числа предприятий отмечалось в федеральных округах (ФО) с их высокой концентрацией - в Центральном и СевероЗападном, а также в Уральском. На общем фоне выделялся Южный ФО, в котором в 2009-2019гг. число предприятий не сократилось, а, наоборот, выросло. Вероятно, стимулами для сохранения и увеличения количества предприятий в нем стали импортозамещение и рост производства продукции аграрного сектора, а также строительство различного рода инфраструктурных объектов после вхождения в его состав Крыма.

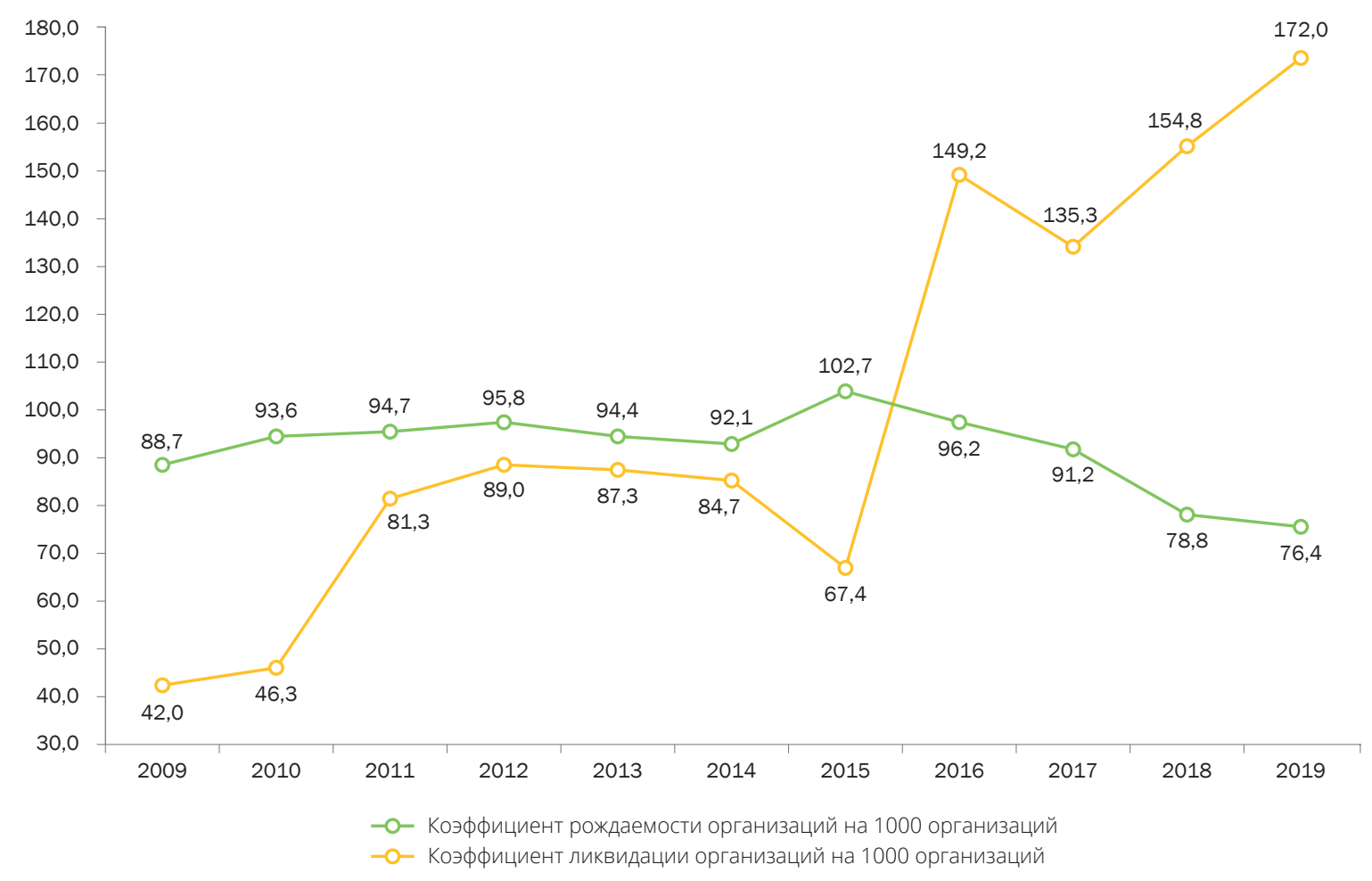

Рис. 3. Соотношение рождаемости и официальной ликвидации организаций по России, количество организаций/1000

Источник: Агрегированные данные Pосстата по трудовым ресурсам, 2020 г. 
В 2009-2019 гг. не только ликвидировались, но и рождались новые организации. Соотношение между рождением и ликвидацией организаций варьировалось в течение данного периода. В 2009-2015 гг. коэффициент рождаемости превышал коэффициент ликвидации организаций. После 2016 г. тренд в соотношении рождения и ликвидации организаций поменялся. С ухудшением макроэкономической ситуации, а также под воздействием ограничений от введения второй волны экономических санкций после 2016 г. коэффициент ликвидации организаций стал значительно превосходить коэффициент их рождаемости (рис. 3).

Выявленные тренды рождаемости и ликвидации организаций были схожими в большинстве отраслей экономики. Исключение составляли только две отрасли - образование и здравоохранение. В образовании коэффициент ликвидации организаций стал расти гораздо раньше (с 2009 г.) по сравнению с другими отраслями экономики (с 2015-2016 гг.). При этом коэффициент рождаемости организаций в образовании начал заметно снижаться с 2015 г., практически одновременно с другими видами экономической деятельности. Здравоохранение оказалось единственным видом экономической деятельности, в котором на протяжении 2009-2019 гг. рождение организаций превышало их ликвидацию. В результате число организаций здравоохранения оставалось все годы относительно стабильным.

При низком показателе рождаемости организаций по России в целом наиболее высокие его значения наблюдались в Центральном, Приволжском, Северо-Западном и Сибирском ФО. В 2019 г. положительное сальдо между рождаемостью и ликвидацией организаций отмечалось только в некоторых регионах России: в Ленинградской области, в Ингушетии и Чеченской Республике, а также в Республике Бурятия и в Чукотском автономном округе. 


\section{2. Наем и увольнения рабочей силы}

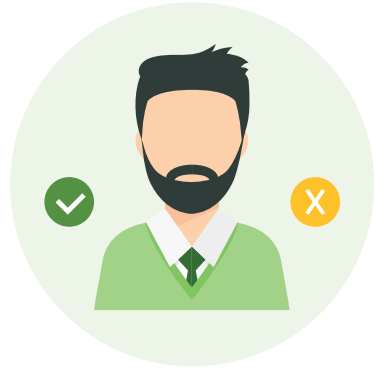

Выбытие работников

опережало их наем
В 2009-2019 гг. предприятия нанимали и увольняли работников, формируя потоки движения рабочей силы на рынке труда. На протяжении всех лет коэффициенты выбытия работников превышали коэффициенты их найма. Наибольшее отставание найма от увольнений работников отмечалось в период кризиса 2009 г., а также в 2015 г. с расширением против России экономических санкций (рис. 4).

Наем работников оказался подверженным влиянию макроэкономических шоков и воздействию экономических кризисов. Он снижался в кризисные периоды и восстанавливался по мере адаптации экономики при выходе из кризиса. Например, в 2015 г. из-за расширения списка экономических санкций произошел провал найма работников. Но по мере стабилизации и улучшения экономической ситуации наем работников постепенно рос, и после 2016 г. он приблизился к уровню посткризисных лет (2011-2012 гг.).

Увольнения работников демонстрировали зависимость от общемировых финансовых шоков. Максимально высокие значения коэффициентов выбытия работников наблюдались в 2009 г., в 2010 г. они снизились и оставались в пределах 28-30\% все последующие годы. Введение экономических санкций против России не привело к значительному выбытию работников с предприятий (рис. 4).

Во-первых, санкции коснулись не всех отраслей экономики и не в равной степени (рис. 5). После введения санкций импульс 


\section{Основные понятия}

Численность принятых работников - лица, зачисленные в отчетном периоде в организацию приказом (распоряжением) о приеме на работу, переведенные на работу из другой организации.

Численность выбывших работников - лица, оставившие в отчетном периоде работу независимо от оснований, уход или перевод которых оформлен приказом (распоряжением).

Коэффициент найма - отношение численности принятых работников к среднесписочной численности работников в отчетном периоде.

Коэффициент выбытия (увольнения) - отношение численности выбывших работников к среднесписочной численности работников в отчетном периоде.

Сальдо движения рабочей силы, или итоговое изменение занятости, - разница между коэффициентом найма и коэффициентом выбытия рабочей силы в отчетном периоде.

Валовой оборот рабочей силы - сумма коэффициентов найма и выбытия рабочей силы в отчетном периоде.

Источник: [Гимпельсон и др., 2012].

для развития получили отрасли экономики, которые относительно слабо зависят от импортозамещения (например, торговля, сфера услуг) и ориентированы на местного потребителя (например, сельское хозяйство, пищевая промышленность). Предприятия этих отраслей смогли относительно быстро занять нишу выбывших с рынка игроков и заместить импортные продукты.

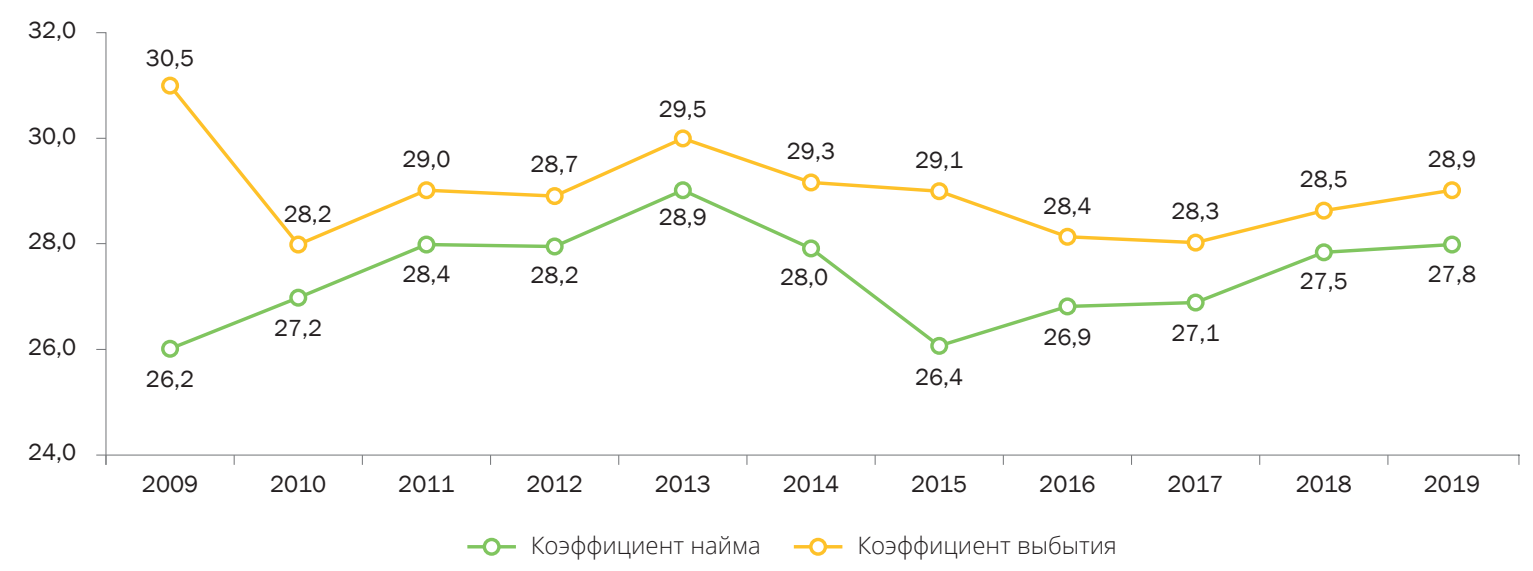

Рис. 4. Движение рабочей силы в 2009-2019 гг., \% Источник: Агрегированные данные Росстата по трудовым ресурсам, 2020 г. 


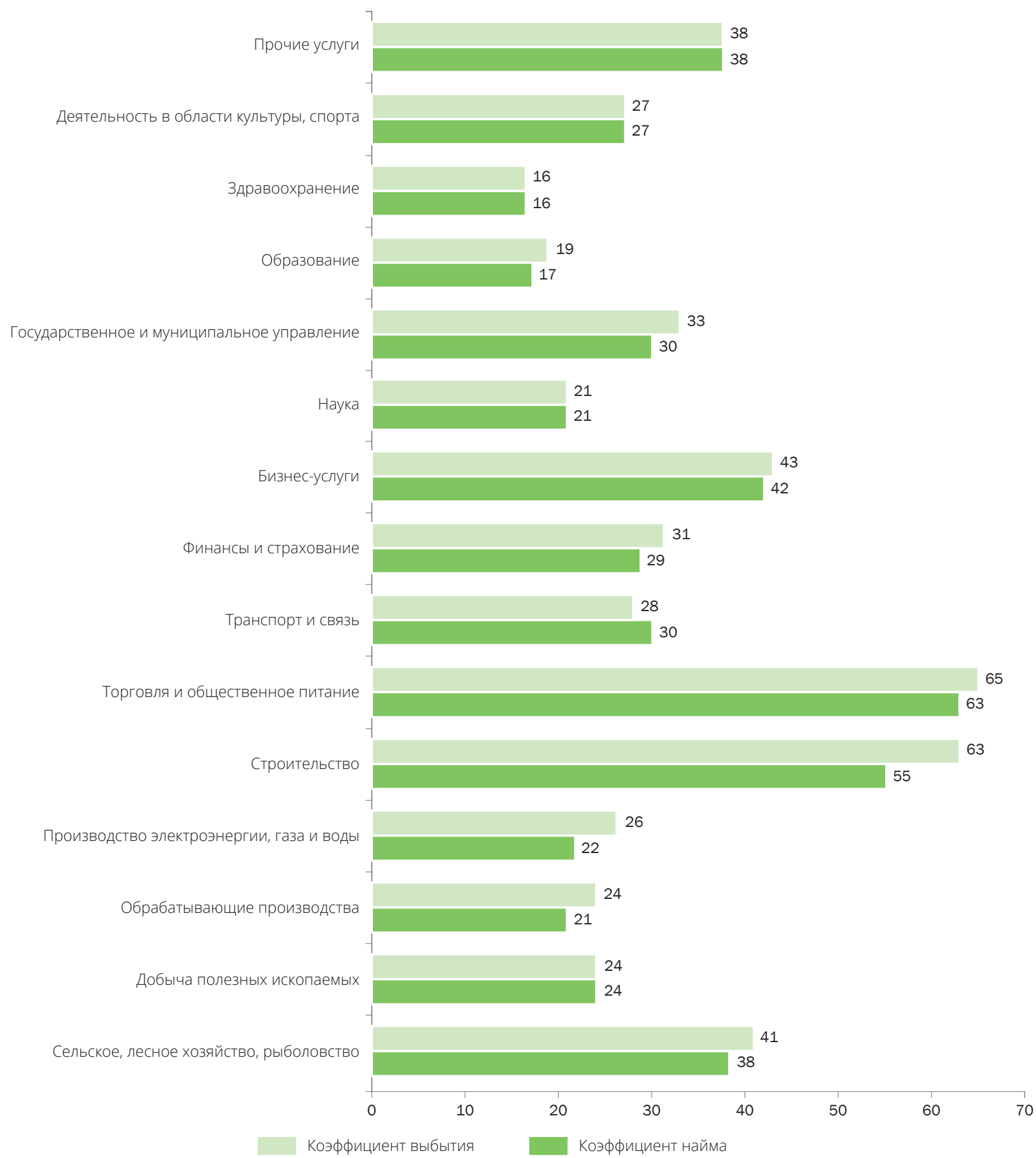

Рис. 5. Движение рабочей силы по видам экономической деятельности в 2019 г., \% Источник: Агрегированные данные Росстата по трудовым ресурсам, 2020 г.

Во-вторых, высвобождаемые работники часто находили место работы и аккумулировались в отраслях экономики, которые имели либо государственную поддержку (например, строительство), либо постоянно высокий спрос на рабочую силу (например, торговля и общественное питание). В этих отраслях экономики в течение всего периода были самые высокие показатели найма. С одной стороны, эти отрасли имеют сезонный характер и подвержены колебаниям конъюнктуры. С другой стороны, в них 
заняты высокая доля работников с низкой квалификацией, которые относительно легко могут быть заменены. Как следствие, эти отрасли экономики часто высвобождают, но и часто нанимают работников, отличаясь высокой волатильностью рабочей силы по сравнению с другими отраслями экономики (рис. 5).

На показатели найма и высвобождения рабочей силы оказывали влияние различия регионов по уровням экономического роста и по демографической структуре. В 2019 г. максимальное по модулю отрицательное сальдо между наймом и выбытием работников было зафиксировано в Дальневосточном (-3,5\%) и Северо-Кавказском (-2,6\%) ФО. среди регионов России максимально отрицательным было сальдо в Камчатском крае $(-8,1 \%)$ и Магаданской области (-8\%) (рис. 6). Предприятия этих регионов значительно чаще увольняли, чем нанимали, работников по сравнению с другими регионами России. Только в Центральном ФО увольнения и наем работников осуществлялись практически на одинаковом уровне. Положительный вклад в изменение занятости в Центральном ФО вносили Москва $(+0,1 \%)$ и Московская область $(+1,2 \%)$, Тульская $(+0,2 \%)$, Курская $(+0,4 \%)$ и Калужская $(+0,7 \%)$ области (рис. 6). Таким образом, чем дальше регион расположен от центра, тем выше вероятность, что показатели найма работников будут ниже, а вероятность выбытия работников выше, провоцируя рост безработицы на региональных рынках труда.

Это подтверждается различиями уровней безработицы в регионах. В частности, в регионах с отрицательным сальдо движения рабочих мест - в Дальневосточном и Северо-Кавказском ФО - уровень безработицы выше, чем в Центральном².

Создание дополнительных рабочих мест увеличивало уровень найма работников и оказывало положительное влияние на занятость населения. В 2019 г. прием работников на дополнительно создаваемые рабочие места вырос на 9\% по сравнению с 2017 г. В 2019 г. лидером по доле принятых работников на вновь созданные рабочие места был Сибирский ФО. Относительно высокой была доля работников, принятых на вновь созданные рабочие места, в Центральном, Южном и Северо-Западном ФО. Почти в 2 раза она была ниже в Северо-Кавказском ФО, чем в регионах-лидерах (рис. 7).

Отраслями с максимальной долей работников, принятых на дополнительно созданные рабочие места, в среднесписочной численности работников предприятий были строительство (5\%), торговля и общественное питание (3,4\%), финансы и страхование (3,4\%), бизнес-услуги (3,5\%). Минимальная доля работников, принятых на дополнительно созданные рабочие места, зафиксирована в образовании $(0,7 \%)$ и здравоохранении $(0,3 \%)$.

Предприятия, которые сокращали рабочие места или планировали их ликвидацию, намечали численность работников к высвобождению․ В 2019 г. максимальная доля

\footnotetext{
2 В 2018 г. уровень безработицы в Дальневосточном ФО (6,3\%) был в 2 раза, а в Северо-Кавказском ФО (10,5\%) в 3 раза выше, чем в Центральном (2,9\%) [Росстат, 2019].

${ }^{3}$ Согласно статистической отчетности предприятий (форма П-4), к численности работников, намеченных к высвобождению, не относят работников, у которых в ближайшем отчетном периоде заканчивается срочный трудовой договор или которые выходят на пенсию в ближайшем отчетном периоде.
} 

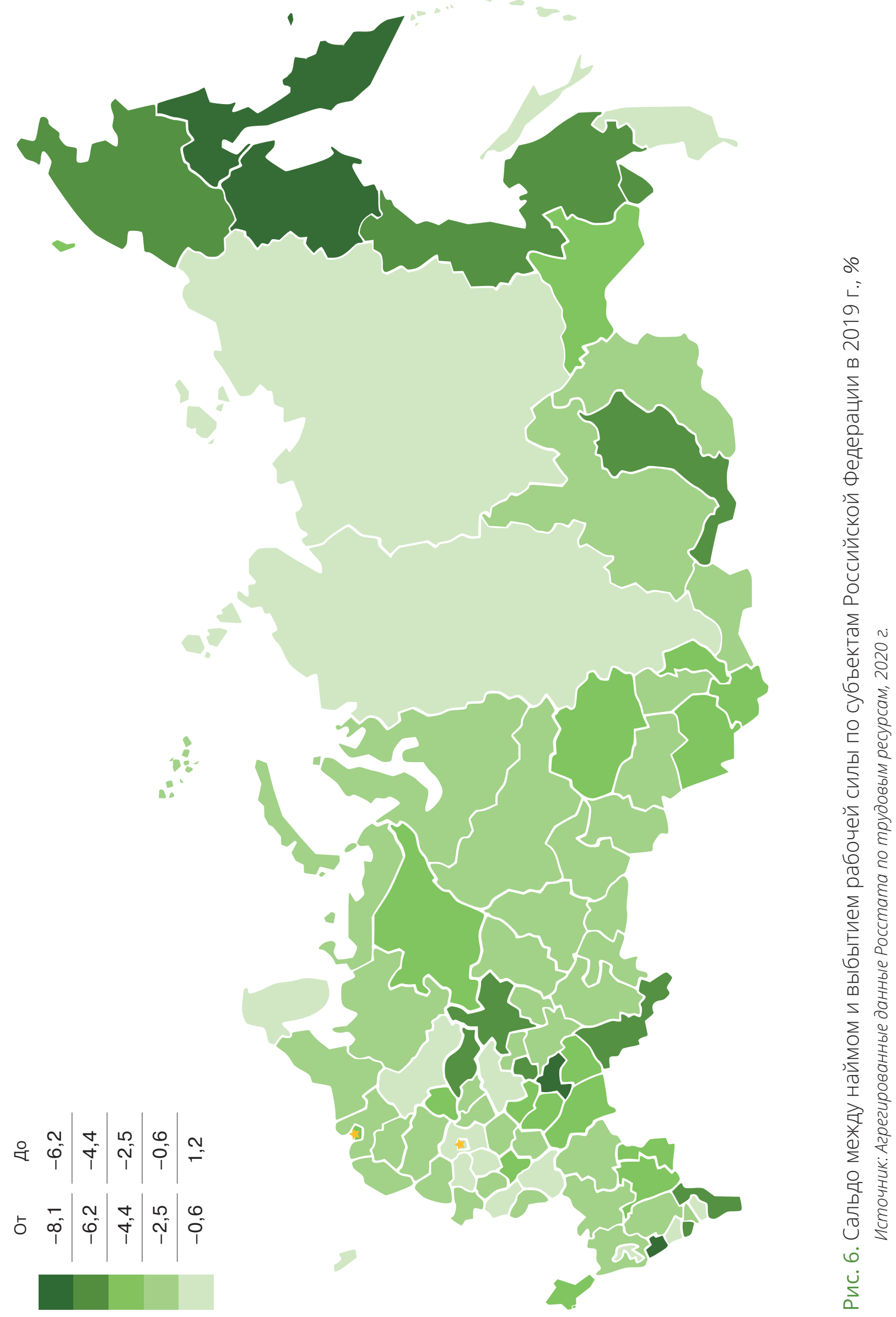


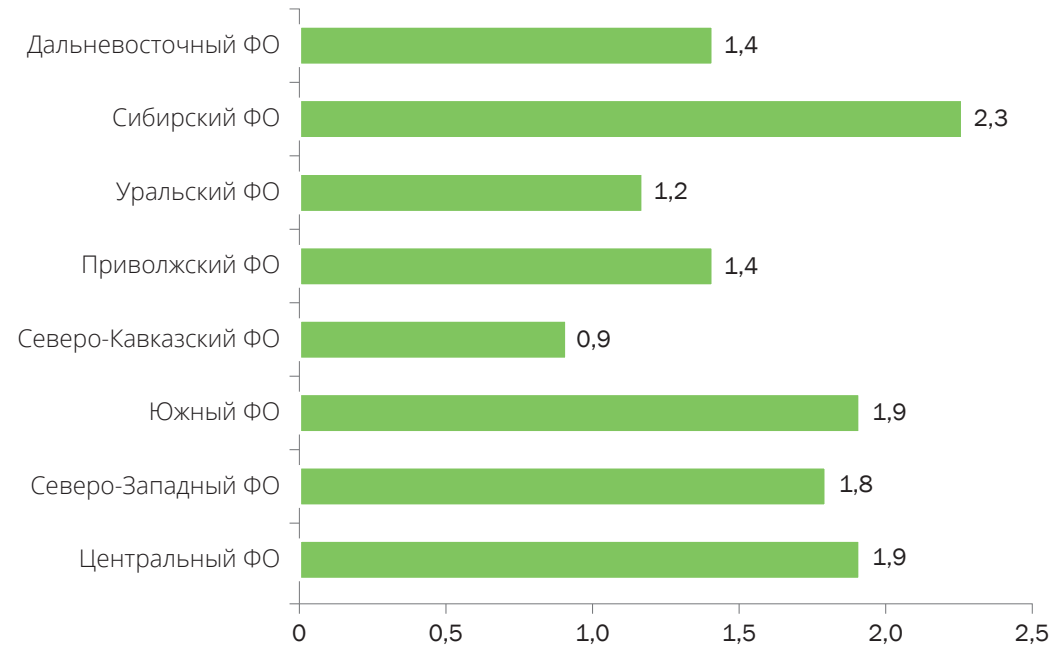

Рис. 7. Доля работников, принятых на дополнительно созданные рабочие места, в среднесписочной численности работников по федеральным округам в 2019 г., \% Источник: Агрегированные данные Росстата по трудовым ресурсам, 2020 г.

работников, намеченных к высвобождению, была в государственном и муниципальном управлении. Вероятно, оптимизация численности и сокращение издержек в этой отрасли происходили одновременно с расширением применения цифровых технологий и переносом ряда услуг в онлайн-формат.

Гораздо меньше намеченных к высвобождению работников наблюдалось в торговле и общественном питании (0,3\%), в образовании и здравоохранении (рис. 8). Эти отрасли экономики также связаны с оказанием услуг населению. Однако в одних из них уже прошли реформы (здравоохранение и образование) и не планировалось дальнейшее массовое высвобождение работников. В других отраслях экономики (торговля) происходили увеличение объемов продаж и рост спроса на рабочую силу.

В 2019 г. лидерами по доле работников, намеченных к высвобождению, были Дальневосточный и Южный ФО (рис. 9). В Дальневосточном ФО наиболее высокая доля работников, намеченных к высвобождению, наблюдалась в Хабаровском крае $(1,4 \%)$, Республике Саха (Якутия) (1,5\%), Еврейской автономной области (1,2\%). В Южном ФО лидерами по доле намеченных к высвобождению работников были Республика Крым (1,5\%), Ростовская область (1,4\%), город Севастополь (1,3\%).

Высокая доля работников, намеченных к высвобождению, отмечалась также в ряде депрессивных регионов, переживающих экономический упадок, снижение уровня жизни населения, имеющих плохую экологию, рост заболеваемости, преступности и др. Это Владимирская (1,2\%) и Оренбургская области (1,4\%), Республика Карелия (1,3\%), Красноярский $(1,2 \%)$ и Пермский $(1,2 \%)$ края. В регионах с относительно благополучной экономической ситуацией, в которых либо был выше уровень жизни населения (Белгородская (0,1\%) и Томская (0,1\%) области), либо лучше экология (Чеченская Республика $(0,1 \%))$, чем во многих остальных регионах России, доля работников, намеченных к высвобождению, была минимальной. 


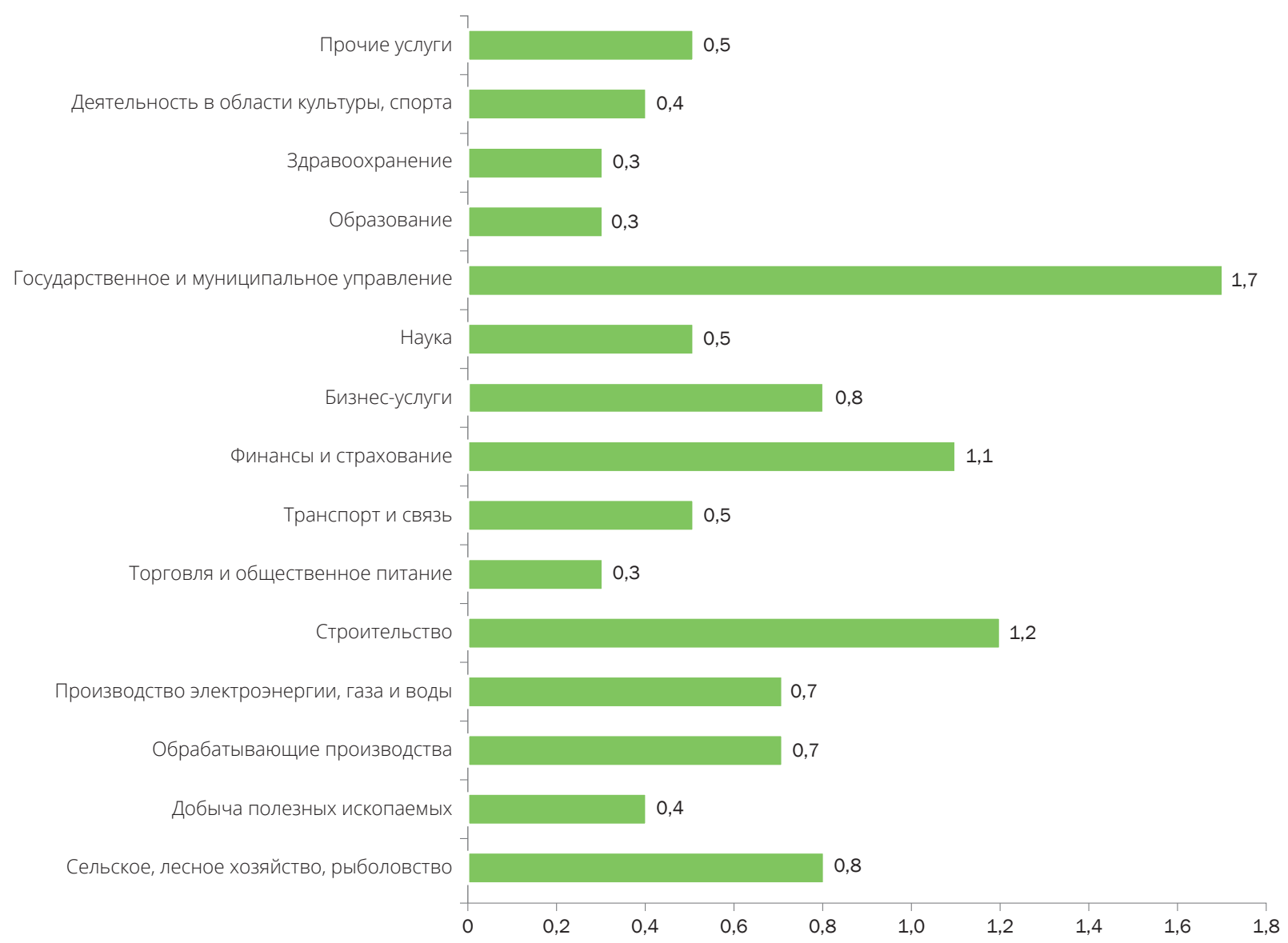

Рис. 8. Доля работников, намеченных к высвобождению, в среднесписочной численности работников предприятий по видам экономической деятельности в 2019 г., \% Источник: Агрегированные данные Росстата по трудовым ресурсам, 2020 г.

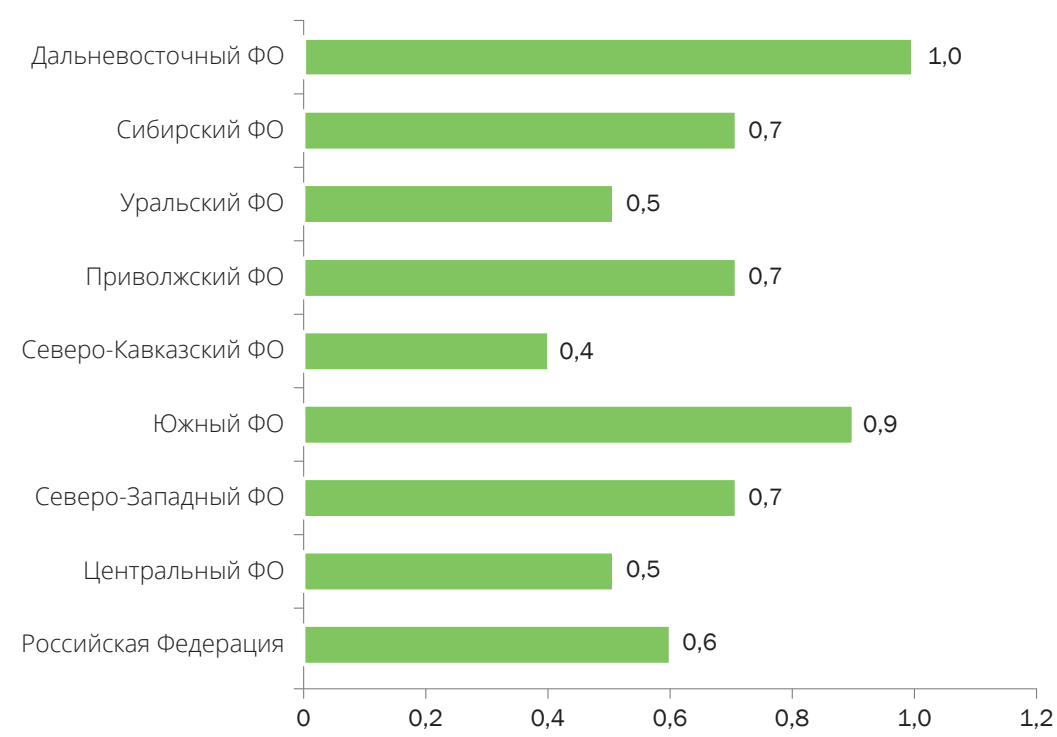

Рис. 9. Доля работников, намеченных к высвобождению, в среднесписочной численности работников по федеральным округам Российской Федерации в 2019 г., \% источник: Агрегированные данные Росстата по трудовым ресурсам, 2020 г. 
Высвобождения работников с предприятий происходили как добровольно, так и вынужденно. В целом считается, что увольнения, произошедшие по инициативе работника, являются добровольными, а по инициативе работодателя - вынужденными. В 2009-2019гг. доминировали добровольные увольнения работников. На них приходилось 70-80\% от общего числа увольнений. При этом вынужденные увольнения составляли соответственно 20-30\%.

Вынужденные увольнения работников происходили в связи с сокращением персонала предприятий, осуществлялись по соглашению сторон (работников и работодателей), по завершении действия трудового договора и др. Максимальная доля вынужденных увольнений была зафиксирована в 2015-2016 гг., в период ухудшения макроэкономических показателей и адаптации экономики России к расширенному списку экономических санкций.

Среди вынужденных увольнений преобладали «прочие увольнения», к которым относились, например, увольнения по завершении срока действия срочных трудовых договоров. На втором месте находились увольнения по соглашению сторон. Минимальной была доля увольнений в связи с сокращением работников (рис. 10). Таким образом, даже в периоды кризисов и при ухудшении макроэкономической ситуации предприятия предпочитали не сокращать работников. Они чаще использовали стратегию гибкости за счет срочных трудовых договоров и других видов нестандартной занятости. Перевод части рабочей силы на нестандартные виды занятости позволял им осуществлять «мягкое» выдавливание рабочей силы в периоды кризисов и увеличивать ее численность в периоды подъема экономики.

Однако при относительно невысоком уровне увольнений работников в связи с сокращением по стране в целом (2,3\%) значения его существенно варьировались по

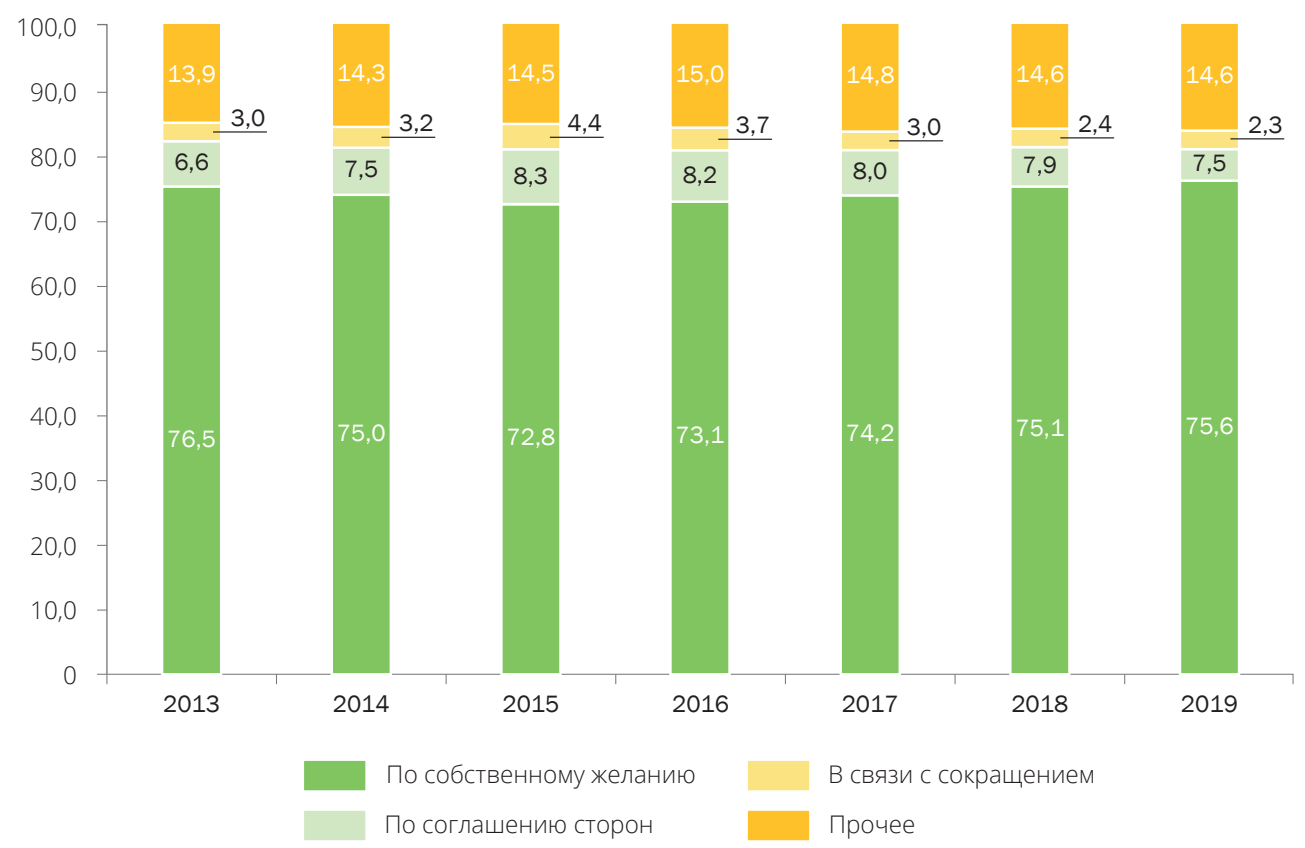

Рис. 10. Причины выбытия работников, \% Источник: Агрегированные данные Росстата по трудовым ресурсам, 2020 г. 


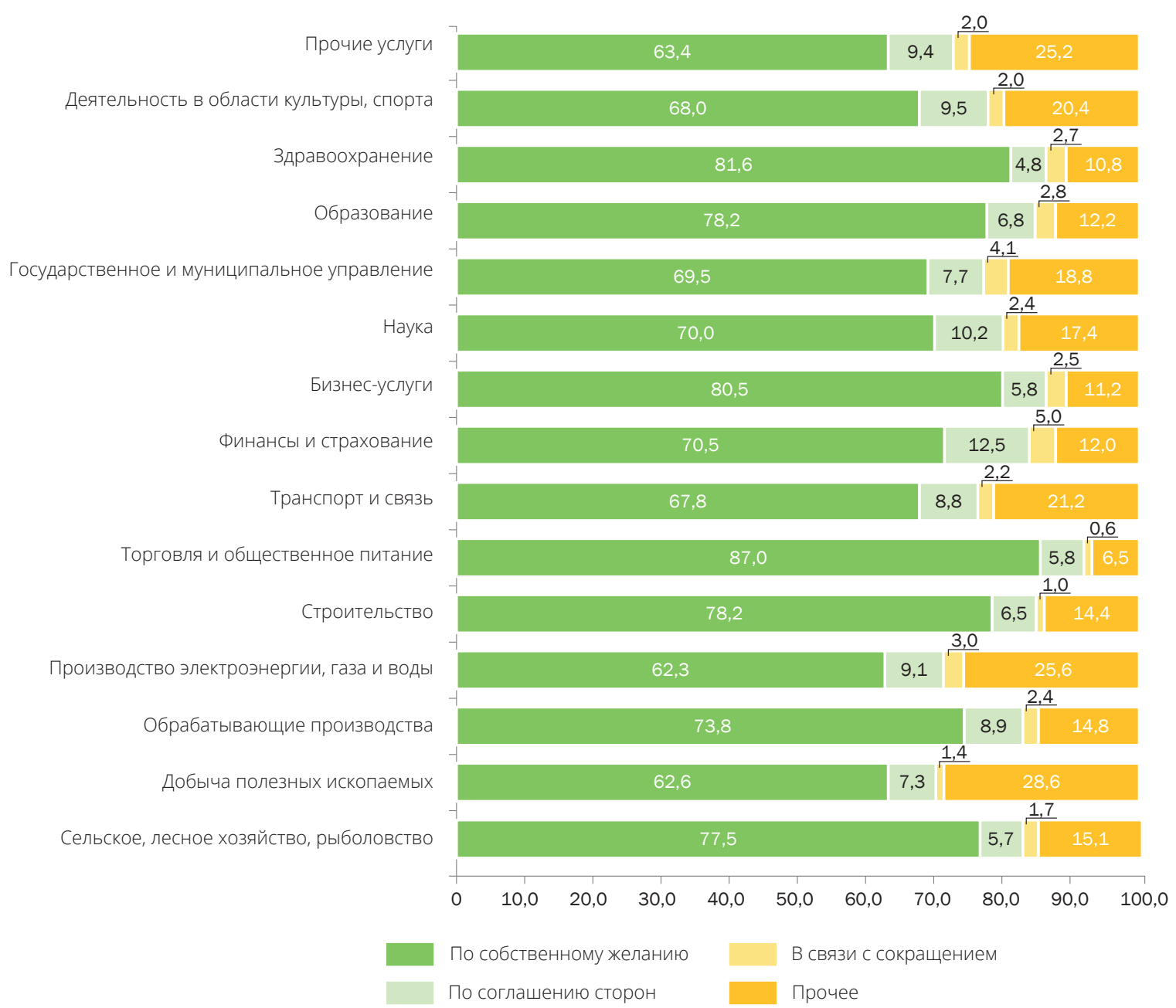

Рис. 11. Причины выбытия работников по видам экономической деятельности предприятий, 2019 г., \%

Источник: Агрегированные данные Росстата по трудовым ресурсам, 2020 г.

отраслям экономики. В 2019 г. доля увольнений в связи с сокращением работников была практически в 2 раза выше в сфере финансов и страхования (5\%), а также в государственном и муниципальном управлении (4\%) по сравнению с общероссийским уровнем (рис. 11). Если увольнения в сфере финансов и страхования были, скорее всего, связаны с падением спроса на товары и услуги этой отрасли, то увольнения в государственном и муниципальном управлении происходили, вероятно, в результате структурных преобразований и оптимизации численности работников этой сферы.

Вынужденные увольнения различались по регионам незначительно, находясь в пределах 2-3\%. Намного выше между регионами была дифференциация добровольных увольнений. В 2019 г. доля добровольных увольнений была минимальной в Дальневосточном ФО (69\%) и максимальной в Центральном ФО (79\%) (рис. 12). В этих федеральных округах наблюдались значительные различия в напряженности 4

\footnotetext{
${ }_{4}^{4}$ Напряженность на рынке труда измеряется уровнем безработицы, отношением численности безработных в рас чете на одну вакансию, временем поиска работы безработными, а также удельным весом безработных, ищущих работу на рынке труда 12 месяцев и более [Росстат, 2019].
} 


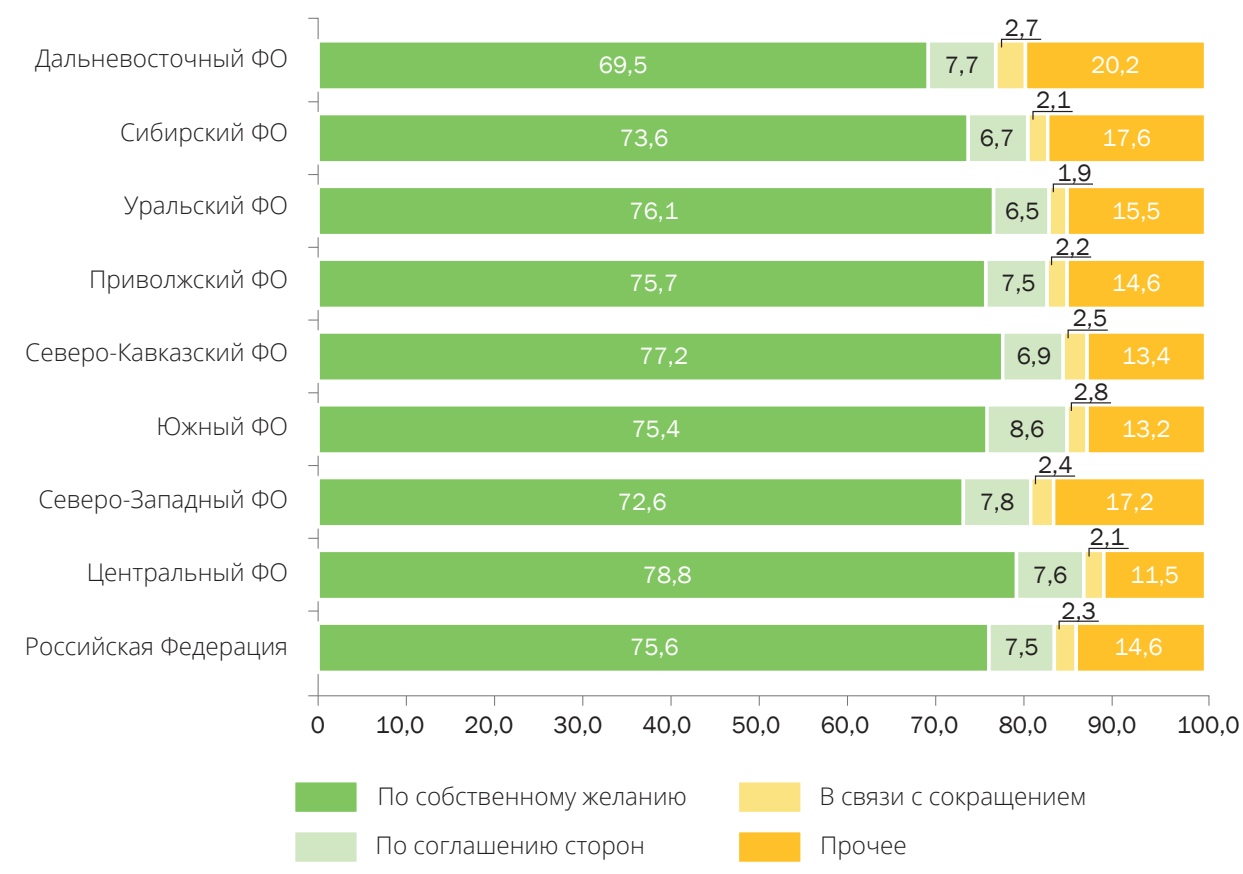

Рис. 12. Причины выбытия работников по федеральным округам России, 2019 г., \% Источник: Агрегированные данные Pосстата по трудовым ресурсам, 2020 г.

на региональных рынках труда. Если в Центральном ФО уровень безработицы в 2019 г. составлял 4,4\%, то в Дальневосточном - 6,3\%5. Доля безработных, ищущих работу на рынке труда 12 месяцев и более, в Центральном ФО равнялась 25,7\%, а в Дальневосточном - 34,1\% [Росстат, 2019]. Поскольку ситуация на региональном рынке труда в Дальневосточном ФО была более напряженной, чем в Центральном ФО, работники Дальневосточного ФО были менееуверены, что при добровольном увольнении смогут найти работу, поэтому увольнялись реже, чем работники Центрального ФО.

Конечно, работники могут искать место работы не только в регионе проживания, они могут переезжать в поисках работы и в другие регионы. Но в силу больших расстояний, а также высоких издержек переезда и других причин многие жители Дальневосточного ФО остаются в своем регионе. При этом из-за напряженности на региональном рынке труда они менее склонны к добровольным увольнениям по сравнению с жителями других федеральных округов России. 


\section{3. Соотношение между перераспределениями рабочей силы и рабочих мест}

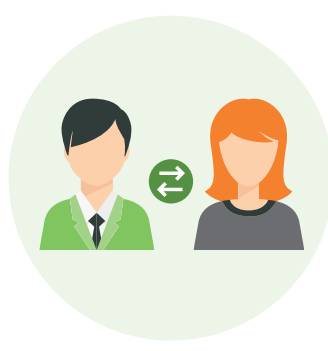

Увеличилась доля холостого оборота в валовом обороте рабочей силы
Перемещения работников на рынке труда могут быть продиктованы перераспределениями рабочих мест между предприятиями или осуществляться независимо от них. Часть движения рабочей силы, которая не связана с движением рабочих мест, называется холостым оборотом рабочей силы. С одной стороны, рост холостого оборота рабочей силы может быть продиктован необходимостью подбора работника, соответствующего качественным характеристикам и требованиям рабочего места. Этот процесс «притирки» может быть длительным. Однако за счет «притирки» между качественными характеристиками рабочей силы и рабочих мест может расти производительность труда. С другой стороны, холостой оборот рабочей силы может повышаться по причине ограниченного количества рабочих мест или наличия в экономике рабочих мест низкого качества. В этих условиях за счет найма и увольнений повышается гибкость и сокращается продолжительность занятости на одном месте работы, что может приводить к росту издержек участников рынка труда и сдерживать экономический рост. Таким образом, на основе показателей холостого оборота можно судить о характере и эффективности функционирования экономики и росте производительности труда.

На протяжении 2009-2019 гг. валовой оборот рабочей силы оставался относительно стабильным, а валовой оборот рабочих мест значительно снизился после 2016 г. (рис. 13). Как следствие, 


\section{Основные понятия}

Валовой оборот рабочей силы - сумма коэффициентов найма и выбытия рабочей силы в отчетном периоде.

Валовой оборот рабочих мест - сумма коэффициентов создания и ликвидации рабочих мест в отчетном периоде.

Холостой оборот рабочей силы - разность между валовым оборотом рабочей силы и валовым оборотом рабочих мест.

Источник: [Гимпельсон и др., 2012].

после 2016 г. движение рабочей силы на российском рынке труда стало меньше связанным с перераспределением (созданием и ликвидацией) рабочих мест по сравнению с предыдущими годами.

В целом доля холостого оборота в валовом обороте рабочей силы увеличилась с 63,3\% в 2009 г. до 79,3\% в 2019 г. Движение рабочей силы на российском рынке труда было связано менее чем на треть с процессами создания и ликвидации рабочих мест и примерно на 2/3 - схолостым оборотом рабочей силы.

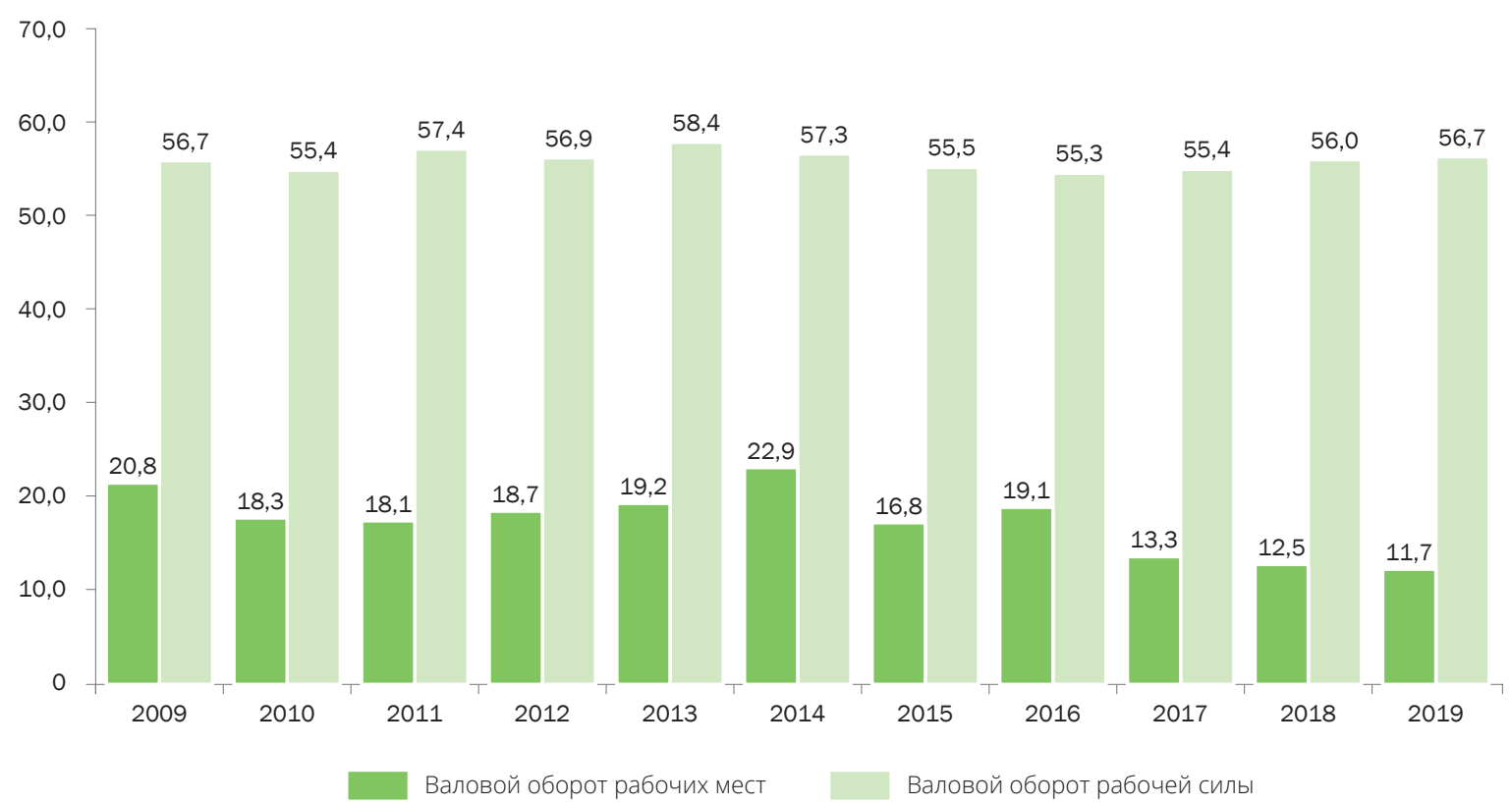

Рис. 13. Соотношение валового оборота рабочей силы и валового оборота рабочих мест, 2009-2019 гг., \%

Источник: Агрегированные данные Росстата по трудовым ресурсам, 2020 г. 
В 2019 г. холостой оборот рабочей силы имел значительный разброс — от 65,8\% в финансах и страховании до 84,9\% в государственном и муниципальном управлении. К отраслям экономики с высокой долей холостого оборота (около 84\%) в валовом обороте рабочей силы относились также сельское и лесное хозяйство, торговля и общественное питание, культура и спорт. В этих отраслях-лидерах общее движение рабочей силы было на 1/5 связано с процессами создания и ликвидации рабочих мест и примерно на 4/5 - с холостым оборотом рабочей силы, т.е. с перемещениями работников между старыми рабочими местами. 


\section{4. Движение рабочей силы и рабочих мест в период пандемии коронавируса ${ }^{6}$}

\section{Создание и ликвидация рабочих мест}

В период пандемии коронавируса и действия карантинных мер (апрель - июль 2020 г.) предприятия, как и все предыдущие годы, продолжали больше ликвидировать, чем создавать, рабочие места. На протяжении всего периода пандемии сальдо между созданием и ликвидацией рабочих мест оставалось отрицательным. Максимальный коэффициент ликвидации рабочих мест и наибольшее отрицательное расхождение между созданием и ликвидацией рабочих мест (отрицательное сальдо) были зафиксированы в мае 2020 г. (рис. 14). В это время многие предприятия, которые не имели возможности вести бизнес дистанционно или быстро переориентировать его на другие (возможно, смежные) виды деятельности, не располагающие в достаточном количестве запасами и накоплениями денежных средств, не получившие поддержку от государства, банков и др., вынуждены были закрываться и ликвидировать рабочие места. В последующие месяцы ситуация стала постепенно нормализовываться, в том числе за счет мер господдержки, и показатели ликвидации рабочих мест снизились практически в 2 раза (рис. 14).

\footnotetext{
${ }^{6}$ Оценки проводились на данных опроса предприятий «Работа в России». В выборку вошли предприятия с численностью работников более 15 человек всех видов экономической деятельности. Размер выборки составил 403908 предприятий. Малые предприятия в выборке насчитывали 84,8\%, средние - 9,6\%, крупные - 5,6\%. 97\% предприятий были непрерывно действующими.
} 


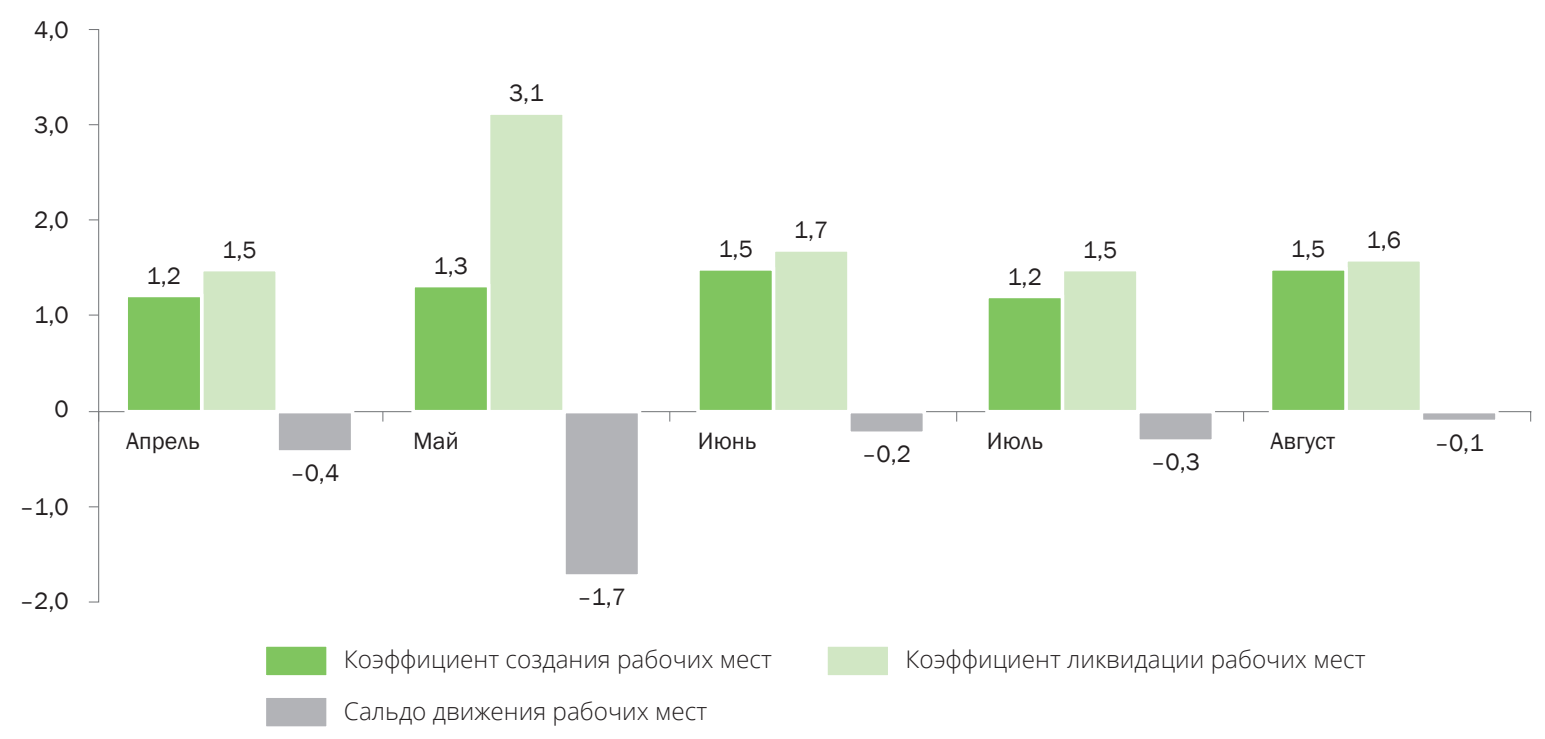

Рис. 14. Движение рабочих мест, \% Источник: Работа в России, апрель - август 2020 г.

В период пандемии коронавируса предприятия продолжали создавать рабочие места. Однако коэффициенты создания рабочих мест были заметно ниже коэффициентов ликвидации рабочих мест. В апреле коэффициент создания рабочих мест равнялся 1,2\%, в мае он увеличился до 1,3\%, а в июне - в период снятия карантинных мер он вырос до 1,5\% (рис. 14). При этом помесячные колебания в показателях создания рабочих мест были менее заметными, чем в показателях ликвидации рабочих мест.

Положительный вклад в создание рабочих мест вносили такие отрасли экономики, как строительство, добыча полезных ископаемых, сельское и лесное хозяйство (рис. 15). В строительном бизнесе это происходило благодаря мерам государственной поддержки (снижение ставок по кредитам застройщиков и надзорной нагрузки, отсрочка и рассрочка по налогам, защита системообразующих организаций от банкротства и др.) [КонсультантПлюс, 2020].

Предприятиям добычи полезных ископаемых, многие из которыхявляются градообразующими, удалось устоять в период пандемии коронавируса за счет субсидий и других мер господдержки.

Сельское хозяйство выжило отчасти за счет своей сезонности. Весенне-летний период пандемии пришелся на активный цикл деятельности сельхозпредприятий. Поскольку большинство видов сельхозработ осуществляются на открытых пространствах (на природе) и не связаны с массовым скоплением людей, угроза распространения коронавируса в этой отрасли оказалась относительно низкой по сравнению с другими видами экономической деятельности. Кроме того, в отрасли продолжали производиться продукты первой необходимости, спрос на которые сохраняется относительно высоким и в условиях кризисов. Как следствие, рост спроса на рабочую силу подталкивал предприятия к созданию рабочих мест. 


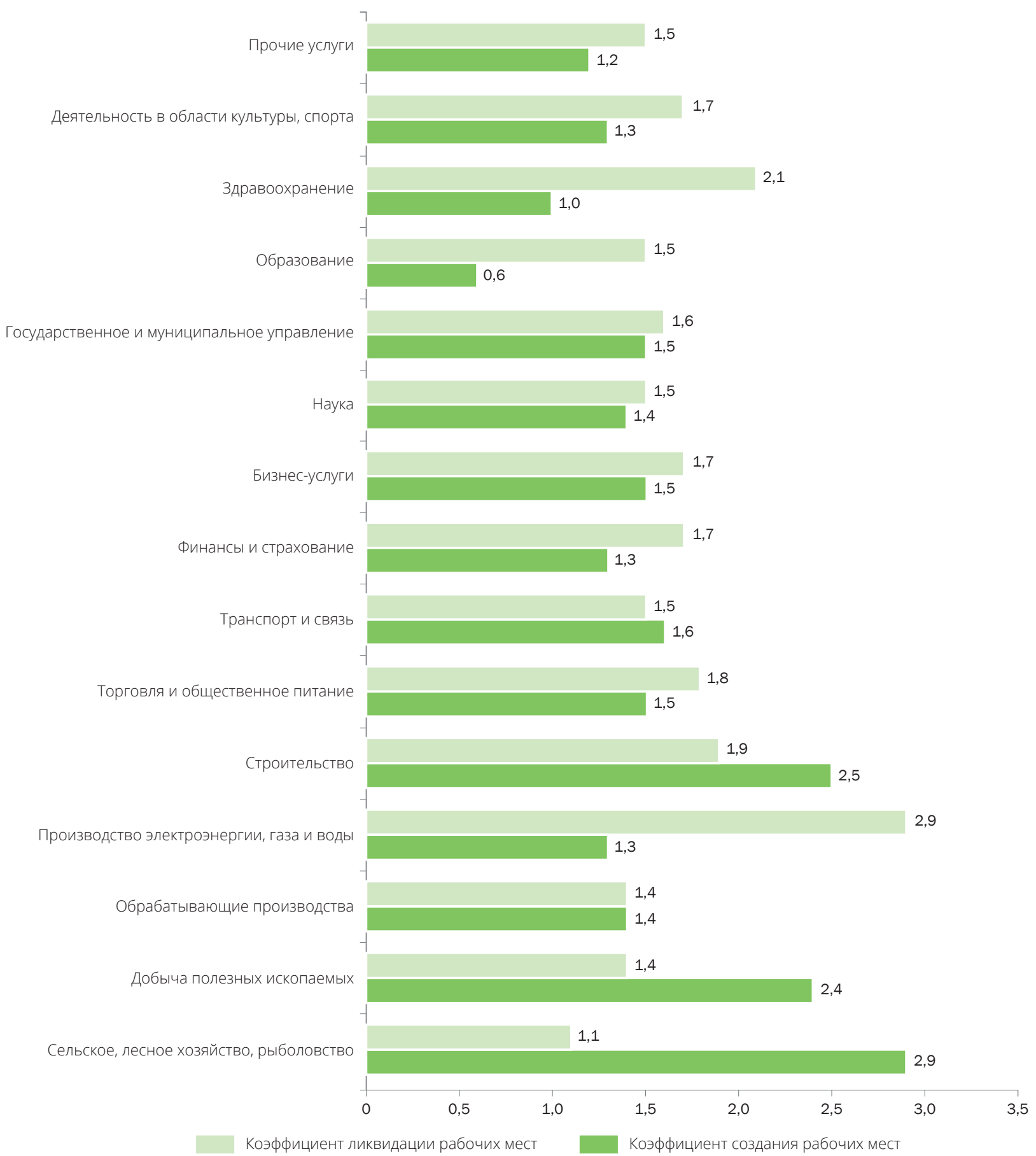

Рис. 15. Движение рабочих мест по видам экономической деятельности, \% источник: Работа в России, апрель - июль 2020 г.

Максимальная ликвидация рабочих мест в период пандемии наблюдалась на предприятиях по производству электроэнергии, газа и воды. Это могло быть связано с ростом неплатежей потребителей продукции и с повышением размера задолженностей предприятий этой отрасли. Кроме того, в условиях действия карантинных мер предприятия отрасли были лишены возможности очередного повышения цен на коммунальные услуги и взыскания образовавшихся задолженностей через суд. В период пандемии из отрасли увеличился отток мигрантов, которые часто формируют ее значительный кадровый 


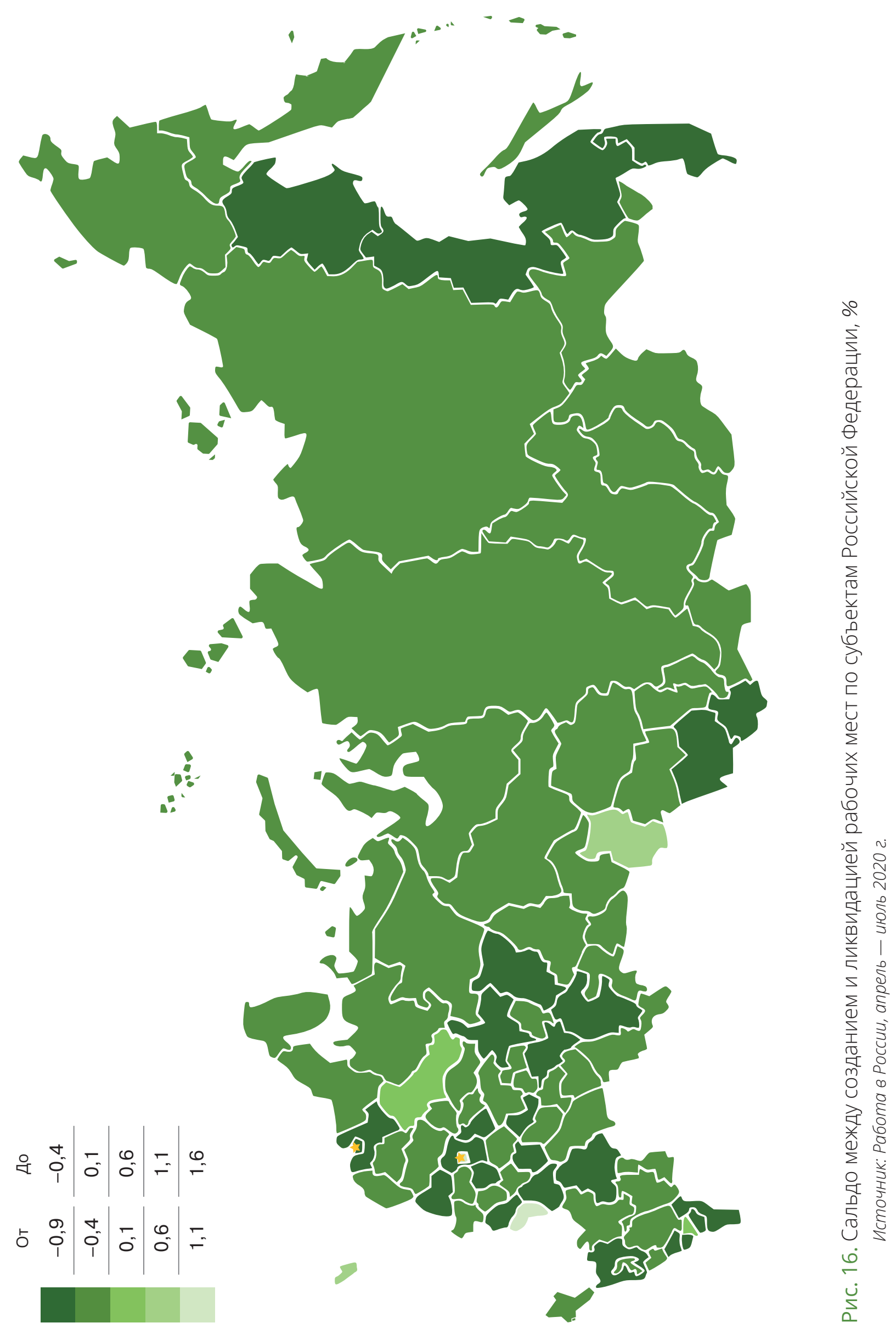


состав. Как следствие, в отрасли могли начаться процессы оптимизации организационной структуры, закрытия посреднических фирм и др., что могло привести к ликвидации рабочих мест.

Различия в уровнях экономического развития и отраслевой структуре регионов России повлияли на межрегиональные вариации в создании и ликвидации рабочих мест в период пандемии коронавируса. Наиболее высокие показатели ликвидации рабочих мест отмечались в Приволжском (1,7\%), Центральном $(1,6 \%)$, Уральском $(1,6 \%)$ и Дальневосточном (1,6\%) федеральных округах. Регионами с максимально высокими коэффициентами ликвидации рабочих мест в период пандемии были Тамбовская и Волгоградская области.

В таких регионах, как Москва и Белгородская область, а также Вологодская и Калининградская области, Республика Крым, Ханты-Мансийский автономный округ, Республика Хакасия, Омская область, Камчатский край, Амурская область, Чукотский автономный округ, даже в период пандемии предприятия больше создавали, чем ликвидировали, рабочие места (рис. 16).

\section{Движение рабочей силы}

В период пандемии коронавируса, как и в предыдущие годы, предприятия больше увольняли, чем нанимали, работников. Отрицательное сальдо между наймом и увольнениями работников наблюдалось в апреле, мае и в июле 2020 г. Значительное отставание найма от увольнений (отрицательное сальдо) было зафиксировано в мае. В последующие месяцы показатели найма работников выросли, что привело к относительному сокращению разницы между наймом и увольнениями (рис. 17).

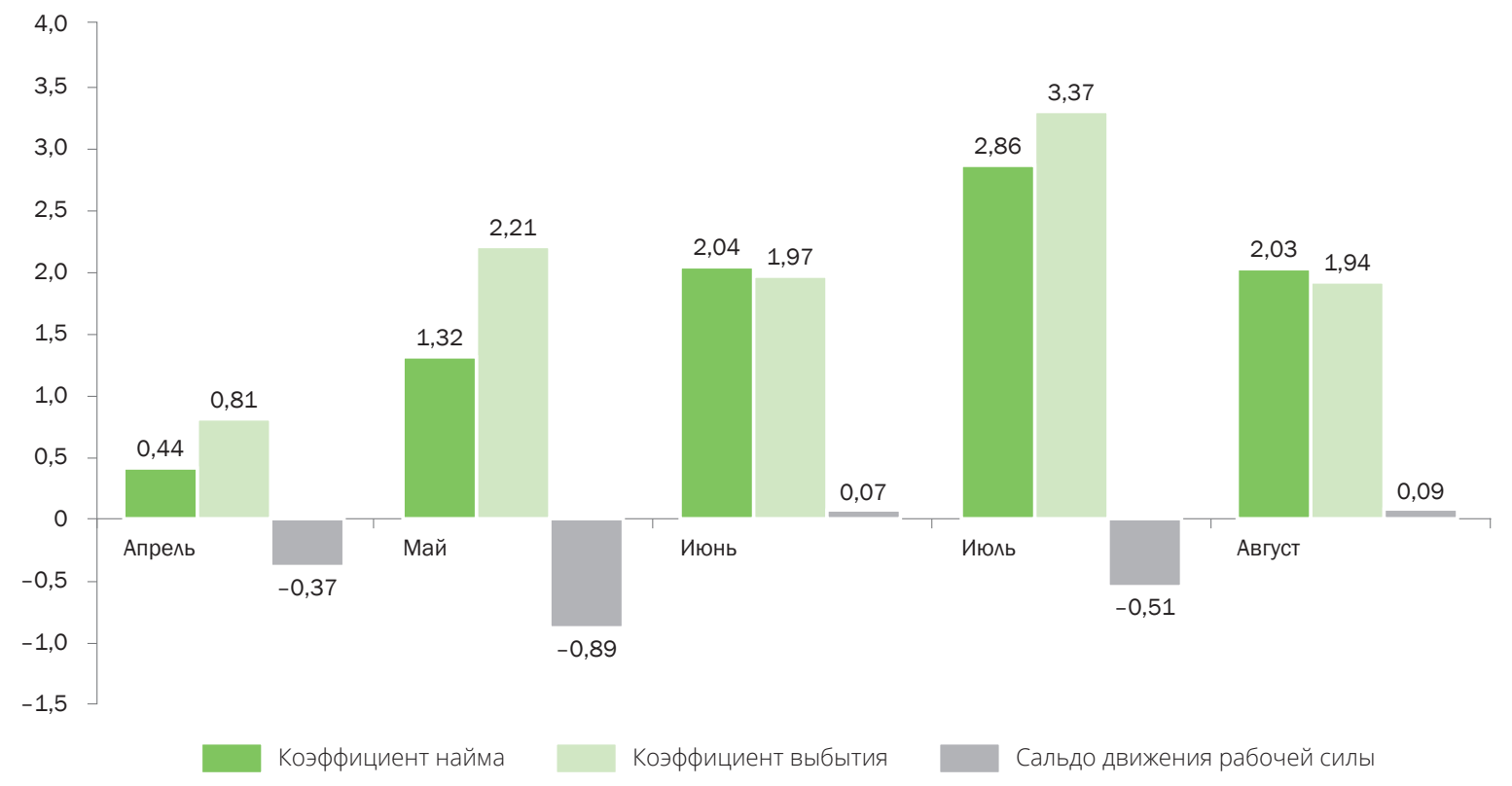

Рис. 17. Движение рабочей силы, \% Источник: Работа в России, апрель - август 2020 г. 
Неожиданным является то, что в условиях пандемии и действия карантинных мер (с апреля по июль) на предприятиях наблюдался рост показателей найма работников. Показатели выбытия рабочей силы были менее стабильными. Они были минимальными в апреле (0,81\%), на начальном этапе введения карантинных мер против пандемии, и достигли максимума в июле (3,37\%), когда большинство предприятий вернулось к своей обычной деятельности и были ослаблены административные барьеры, введенные

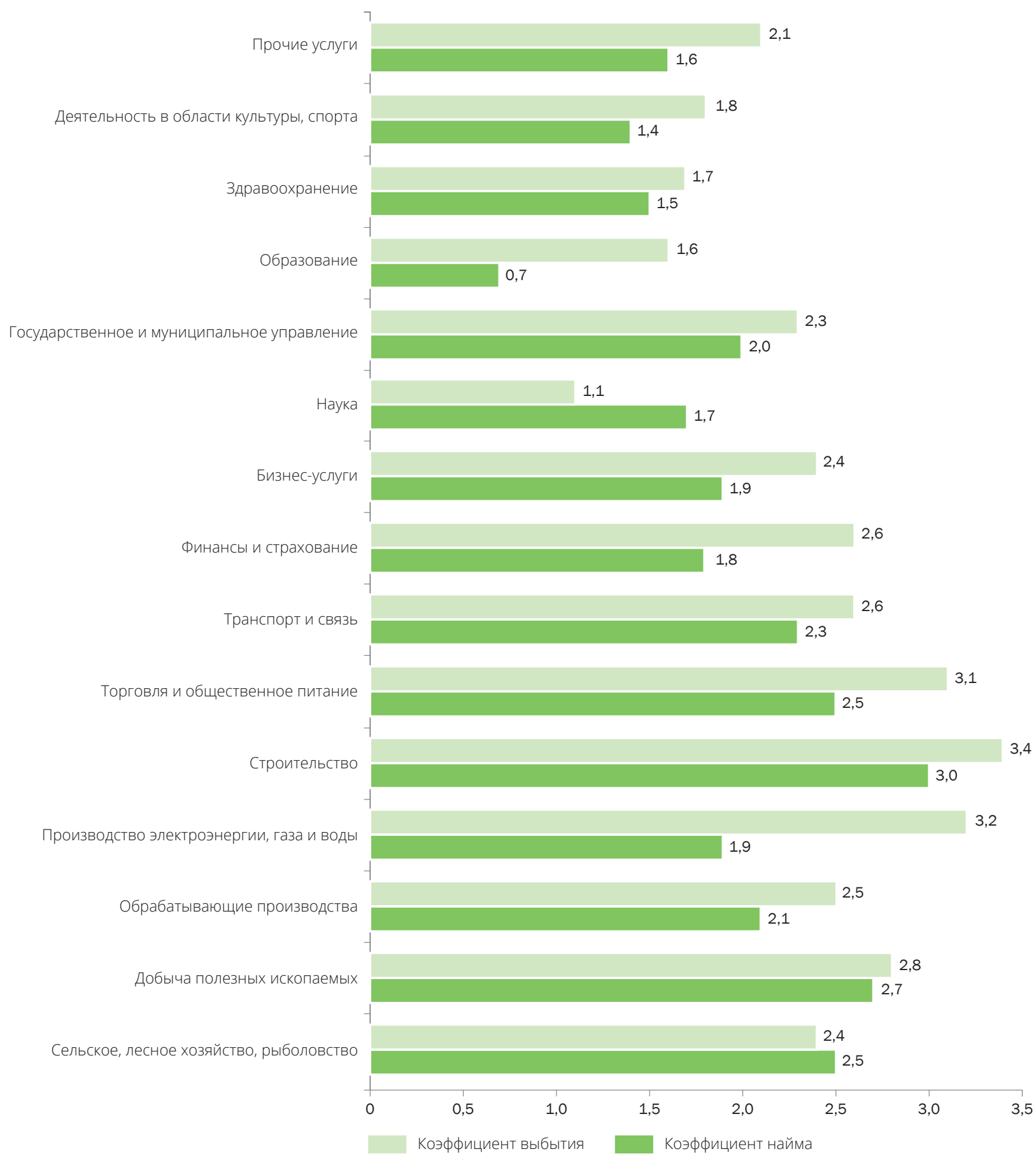

Рис. 18. Движение рабочей силы по видам экономической деятельности, \% Источник: Работа в России, апрель - июль 2020 г. 
Правительством России с целью недопущения безработицы и сдерживания увольнений работников.

Отраслями - лидерами по найму работников в период пандемии были строительство, торговля и общественное питание, а также сельское и лесное хозяйство и добыча полезных ископаемых. Однако только в науке, сельском и лесном хозяйстве предприятия больше нанимали, чем увольняли, работников (рис. 18). Вероятно, это было связано с необходимостью выполнения сельскохозяйственных работ в весенне-летний период, а также с повышением спроса на проведение научных исследований, например, по изучению коронавируса, разработке средств по защите от него и по другим темам.

Лидерами по увольнению работников в период пандемии были строительство, торговля и общественное питание, производство электроэнергии, газа и воды. Строительство, торговля и общественное питание относительно быстро «сбрасывали» рабочую силу при ухудшении экономической ситуации, но также быстро возвращались к ее найму, если ситуация на рынке труда улучшалась.

В период пандемии коронавируса во всех федеральных округах России увольнения доминировали над наймом работников. Лидером по высвобождению работников был

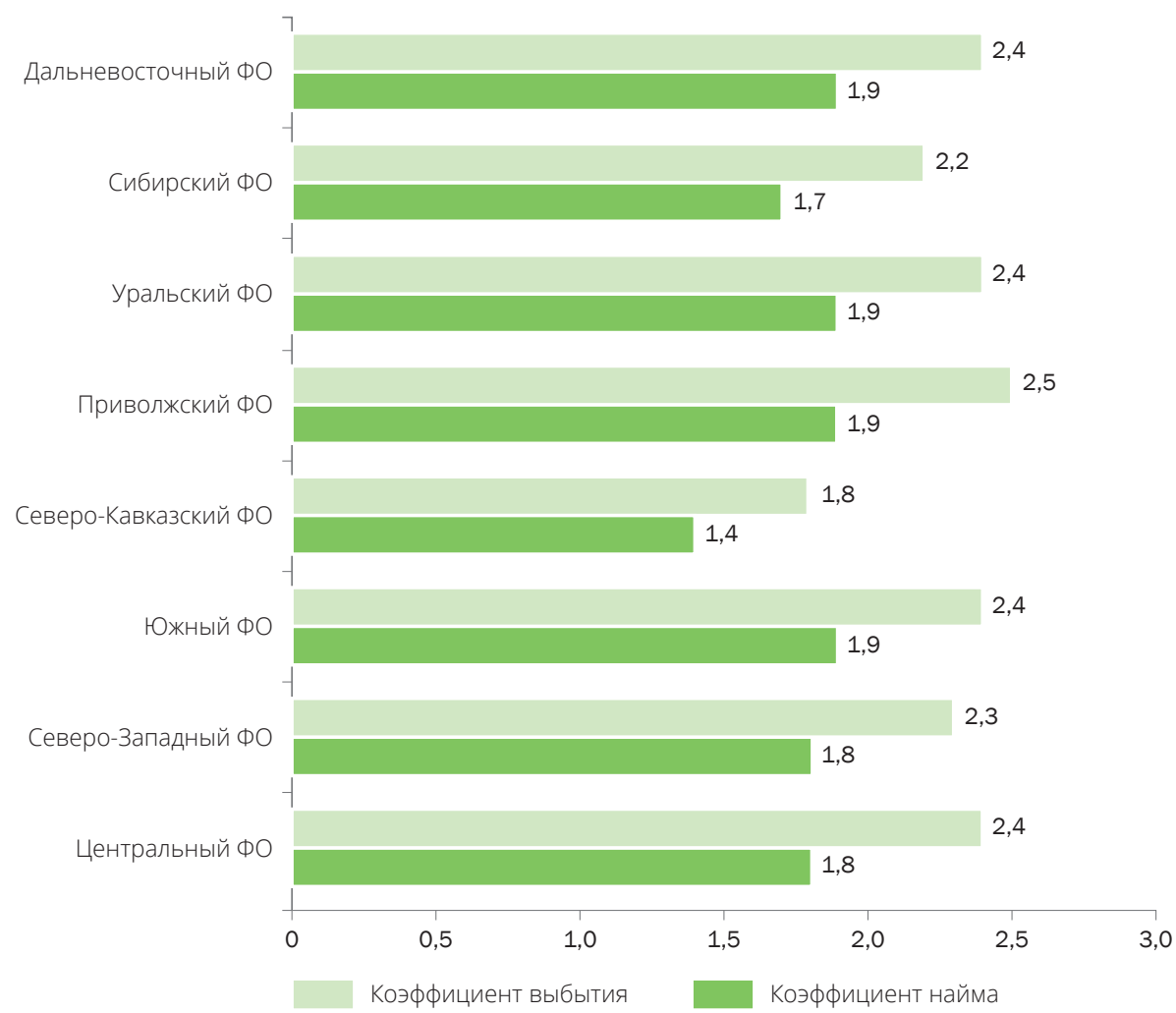

Рис. 19. Движение рабочей силы по федеральным округам, \% источник: Работа в России, апрель - июль 2020 г. 


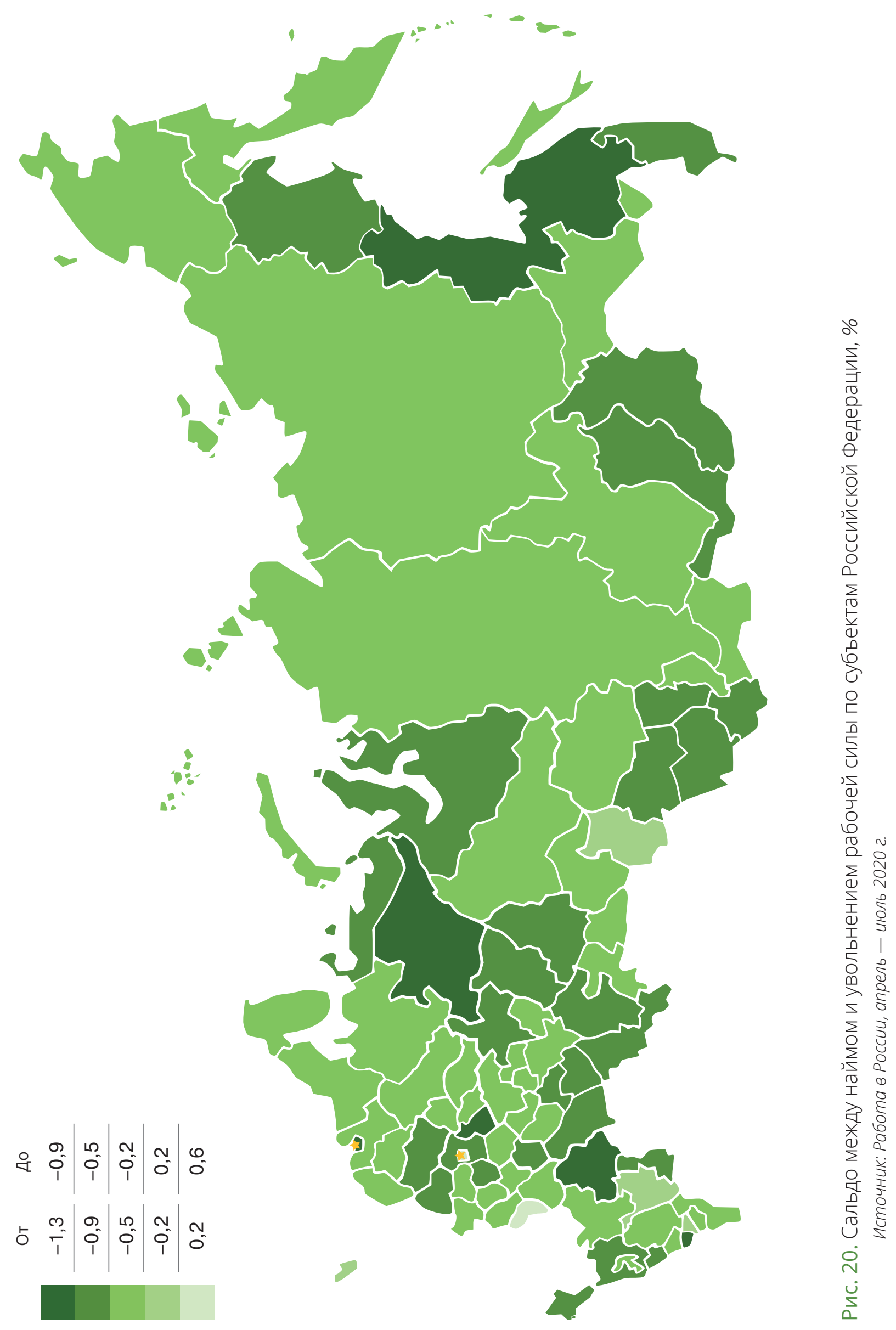


Приволжский ФО, в котором ситуация на рынке труда была неблагоприятной и до пандемии коронавируса (рис. 19).

Только в небольшом количестве регионов (Белгородская, Омская, Калининградская области и город Москва) предприятия в период пандемии чаще нанимали, чем увольняли, работников (рис. 20). Это развитые регионы с предприятиями, получившими господдержку (Белгородская, Омская области), либо регионы, сосредоточившие на своей территории крупные финансовые центры, ритейлерские и торговые сети (Москва), либо приграничные регионы с развитыми центрами импортеров и экспортеров продукции, сырья и др. (Калининград). 


\section{Заключение}

В течение 2009-2020 гг. Россия столкнулась с глобальными вызовами (финансовый кризис 2009 г., цифровизация, пандемия коронавируса) и внутриэкономическими проблемами из-за введенных против нее экономических и политических санкций. Адаптация экономики страны осуществлялась по всем направлениям, в том числе на рынке труда. Это отразилось на показателях найма и выбытия рабочей силы, на создании и ликвидации рабочих мест, которые характеризуют функционирование рынка труда и имеют значение для политики занятости.

Результаты анализа, выполненные на данных Росстата для средних и крупных предприятий и данных «Работа в России», включающих сведения о малых, средних и крупных предприятиях, позволили зафиксировать основные факты, сделать заключения об основных трендах, сложившихся в 2009-2020 гг., и сформулировать прогнозы на ближайшее будущее.

На протяжении всех лет предприятия России больше увольняли, чем нанимали, работников. Наибольший разрыв между наймом и увольнением работников наблюдался в период кризиса 2009 г., а также в 2015 г. после введения против России первой волны экономических санкций. Санкции неодинаково коснулись всех отраслей экономики. Высвобождаемые работники часто находили место работы и аккумулировались в строительстве, торговле и общественном питании. В этих отраслях экономики все годы сохранялись самые высокие показатели найма.

Межрегиональные различия в показателях найма и выбытия рабочей силы были обусловлены различиями в уровнях экономического роста, в демографической структуре и других факторах региональной разнородности (инфраструктура, экология и др.). В 2019 г. наиболее проблемными регионами с точки зрения отставания найма от выбытий работников были Дальневосточный $(-3,5 \%)$ и Северо-Кавказский $(-2,6 \%)$ федеральные округа. Относительно высокие показатели выбытия рабочей силы в проблемных регионах сопровождались ростом безработицы. 
Наиболее благополучной по сравнению с другими регионами России была ситуация в Центральном ФО. Здесь увольнения и наем работников осуществлялись практически на одинаковом уровне. Положительный вклад в изменение занятости в Центральном ФО вносили Москва $(+0,1 \%)$ и Московская область $(+1,2 \%)$, Тульская $(+0,2 \%)$, Курская $(+0,4 \%)$ и Калужская (+0,7\%) области.

Наем работников, который осуществлялся на дополнительно создаваемые рабочие места, вырос в 2019 г. на 9\% по сравнению с 2017 г. В 2019 г. лидером по доле принятых работников на вновь созданные рабочие места был Сибирский ФО. Относительно высокой была доля работников, принятых на вновь созданные рабочие места, в Центральном, Северо-Западном и Южном ФО.

Отраслями - лидерами по доле работников, принятых на дополнительно созданные рабочие места, в среднесписочной численности работников предприятий являлись строительство, торговля и общественное питание, финансы и страхование, бизнесуслуги. Минимальная доля работников, принятых на дополнительно созданные рабочие места, наблюдалась в образовании и здравоохранении.

Предприятия, которые сокращали рабочие места или планировали их ликвидацию, намечали численность работников к высвобождению. В 2019 г. минимальное количество намеченных к высвобождению работников наблюдалось в торговле и общественном питании, в образовании и здравоохранении. Максимальная доля работников, намеченных к высвобождению, была в государственном и муниципальном управлении. Вероятно, оптимизация численности и сокращение издержек в этой отрасли происходили одновременно с расширением применения цифровых технологий и переносом ряда услуг в онлайн-формат.

Лидерами по доле работников, намеченныхквысвобождению, были Дальневосточный и Южный ФО. В Дальневосточном ФО выделялись Хабаровский край (1,4\%), Республика Саха (Якутия) (1,5\%), Еврейская автономная область (1,2\%), в которых доля работников, намеченных к высвобождению, была максимальной. В Южном ФО максимальная доля намеченных к высвобождению работников зафиксирована в Республике Крым (1,5\%), Ростовской области (1,4\%), городе Севастополе (1,3\%).

Однако в части регионов России доля работников, намеченныхк высвобождению, была минимальной. Это касалось Белгородской и Томской областей, Чеченской Республики.

Высвобождения работников на предприятиях происходили как добровольно, так и вынужденно. Доминирующим видом увольнений на российском рынке труда все годы оставались добровольные увольнения (70-80\%). Вынужденные увольнения работников происходили в связи с сокращением персонала предприятий, осуществлялись по соглашению сторон (работников и работодателей), по завершении действия трудового договора и др. Предприятия предпочитали переводить работников на нестандартные виды занятости, постепенно «выдавливая» их на рынок труда в периоды кризисов. И гораздо реже они увольняли работников в связи с сокращением штата. В 2019 г. относительно высокий уровень увольнений в связи с сокращением работников наблюдался 
в финансах и страховании, а также в государственном и муниципальном управлении. Если в сфере финансов и страхования увольнения были связаны, скорее, с падением спроса на товары и услуги этой отрасли, то увольнения в государственном и муниципальном управлении происходили, вероятно, под влиянием структурных преобразований и оптимизации численности работников этой сферы.

Движение рабочих мест является частью движения рабочей силы. В 2009-2019 гг. наблюдалось снижение показателей создания и ликвидации рабочих мест. Под влиянием экономических санкций произошло заметное уменьшение оборота рабочих мест. В 2019 г. валовое перераспределение рабочих мест достигло минимального значения за последние 10 лет. И хотя санкции коснулись не всех отраслей экономики в равной степени, потери рабочих мест в «проседающих» отраслях экономики не компенсировались в полной мере их наращиванием в растущих отраслях экономики. Относительно высокие показатели валового оборота рабочих мест наблюдались в строительстве, финансах и страховании, в бизнес-услугах. Предприятия этих видов экономической деятельности смогли частично компенсировать сокращения рабочих мест на предприятиях других видов экономической деятельности.

В связи с ликвидацией предприятий сокращалось количество рабочих мест на рынке труда. Число предприятий уменьшилось с 4771,9 тыс. в 2009 г. до 4008,5 тыс. в 2019 г. Наибольшее сокращение числа предприятий произошло в федеральных округах с их высокой концентрацией - в Центральном и Северо-Западном, а также в Уральском ФО. На общем фоне выделялся Южный ФО, в котором в течение 2009-2019 гг. число предприятий выросло. На это повлияли развитие аграрного сектора, создание новых рабочих мест по программе импортозамещения, а также строительство в регионе различного рода инфраструктурных объектов после вхождения в его состав Крыма.

Ликвидация старых организаций компенсировалась рождением новых. В течение 2009-2015 гг. коэффициент рождаемости организаций опережал коэффициент их ликвидации. С 2016 по 2019 г. коэффициент рождаемости организаций стал отставать от коэффициента ликвидации организаций. В большинстве отраслей экономики наблюдались схожие тенденции. Исключение составило здравоохранение, в котором в течение 2009-2019 гг. рождение организаций превысило их ликвидацию.

В 2009-2019 гг. разница между валовым оборотом рабочей силы (суммой наймов и выбытий) и валовым оборотом рабочих мест (суммой созданных и ликвидированных рабочих мест) постоянно росла, что отразилось на размере холостого оборота рабочей силы. Доля холостого оборота в валовом обороте рабочей силы выросла с 63,3\% в 2009 г. до 79,3\% в 2019 г. Движение рабочей силы стало связано менее чем на треть с процессами создания и ликвидации рабочих мест и примерно на 2/3 - с холостым оборотом рабочей силы, т.е. с перемещениями работников между старыми рабочими местами.

В 2019 г. относительно низкая доля холостого оборота в валовом обороте рабочей силы наблюдалась в финансах и страховании (65,8\%). Лидерами по холостому обороту рабочей силы являлись сельское и лесное хозяйство, торговля и общественное питание, государственное и муниципальное управление, культура и спорт. В них движение 
рабочей силы на 1/5 было связано с процессами создания и ликвидации рабочих мест и примерно на 4/5 - с холостым оборотом рабочей силы, т.е. с перемещениями работников между старыми рабочими местами.

В период пандемии коронавируса (апрель - август 2020 г.) в движении рабочей силы и рабочих мест продолжили развитие тенденции, которые сложились ранее. Предприятия больше увольняли, чем нанимали, работников, как и в предыдущие годы. Пик увольнений пришелся на июль 2020 г., когда большинство предприятий вернулись к своей обычной деятельности и были ослаблены административные барьеры, введенные Правительством России с целью недопущения безработицы и сдерживания увольнений работников.

Лидером по высвобождению работников в период пандемии коронавируса был Приволжский ФО. Относительно благополучной была ситуация на региональных рынках труда в Белгородской, Омской, Калининградской областях и городе Москве. В этих регионах уровень найма работников превышал уровень увольнений.

Наиболее пострадавшей отраслью экономики в период пандемии коронавируса стало производство электроэнергии, газа и воды. В этой отрасли показатели ликвидации рабочих мест превысили показатели их создания, а увольнения работников происходили чаще, чем наем. Причинами могли стать рост неплатежей потребителей продукции и увеличение размера задолженностей предприятий этой отрасли. Кроме того, в условиях действия карантинных мер предприятия отрасли были лишены возможности очередного повышения цен на коммунальные услуги и взыскания образовавшихся задолженностей через суд.

Положительный вклад в создание рабочих мест в период пандемии коронавируса вносили такие отрасли экономики, как строительство, добыча полезных ископаемых, сельское и лесное хозяйство. Благодаря мерам господдержки, сезонному характеру деятельности и спросу на производство продукции первой необходимости на них удалось не только сохранить, но и увеличить количество рабочих мест.

Возрастание надежд на позитивные сценарии развития экономики привело к оживлению экономической активности и повышению найма работников в июне, в ожидании снятия карантинных мер, и в августе, при затухании пандемии и ожидаемом выходе из нее. Однако надежды на позитивные сценарии оказались преждевременными.

Ликвидация рабочих мест, которая произошла в весенние и летние месяцы 2020 г., не была остановлена и не была перекрыта созданием рабочих мест в последующие месяцы. С началом новой волны пандемии коронавируса - с конца сентября 2020 г. - процесс ликвидации рабочих мест, скорее всего, сохранится, но будет более сдержанным, чем ранее. При этом маловероятно, что до конца 2020 г. создание рабочих мест в большинстве отраслей экономики превысит их ликвидацию. При позитивном сценарии оживления экономики и увеличения количества создаваемых рабочих мест стоит ожидать с началом вакцинации населения от коронавируса, при падении роста заболеваемости и смертности населения от коронавируса. До этого сохранятся высокими показатели 
оборота рабочей силы, которые будут минимально связаны с перераспределением рабочих мест. Предприятия будут по-прежнему больше увольнять, чем нанимать, работников. Более позитивно будет складываться ситуация только в отдельных отраслях экономики. Вероятно, в строительстве, торговле и общественном питании сохранится тренд на превышение найма над увольнениями.

На регионы, в которых в период пандемии коронавируса сложилась напряженная ситуация на рынке труда, должно быть обращено особое внимание для оказания поддержки населению и бизнесу. Это Приволжский, Дальневосточный и Северо-Кавказский ФО. Без дополнительных мер со стороны Правительства ситуация в регионах может усугубиться, что окажет негативное влияние на уровень жизни и повысит социальную напряженность. 


\section{Список литературы}

Гимпельсон В., Жихарева О., Капелюшников Р. Движение рабочих мест: что говорит российская статистика // Вопросы экономики. 2014. № 7. С. 93-126.

Гимпельсон В. Е., Капелюшников Р. И., Рыжикова 3. А. Движение рабочих мест в российской экономике: в поисках созидательного разрушения. Препринт WP3/2012/03.

Лаврентьева И. В., Патракова Д. А. Динамика и статика создания рабочих мест (на примере УрФО и Челябинской области) // Социум и власть. 2017. № 4 (66).

Регионы России. Социально-экономические показатели. М.: Росстат, 2019.

Савельева Т. В., Сурцева А. А. Создание высокопроизводительных рабочих мест в регионах РФ: задачи и результаты // Новая наука: Проблемы и перспективы. 2017. № 1-1. С. 212-215.

Семеньков А. В. Особенности создания и ликвидации рабочих мест в России // Управление экономическими системами: электронный научный журнал. 2014. № 10 (70).

Строительный бизнес: меры поддержки из-за коронавируса // КонсультантПлюс. 2020. <http://www.consultant.ru/document/cons_doc_LAW_353017/>.

Davis S. J., Haltiwanger J. Gross job flows // Handbook of Labor Economics. 1999. Vol. 3.

P. 2711-2805. 
Электронное информационное издание

Л. И. Смирных, Н. Емелина

\title{
Движение рабочей силы и рабочих мест на российском рынке труда: факты, тенденции, перспективы
}

Информационный бюллетень

\author{
Под научной редакцией С.Ю. Рощина, Л.И. Смирных \\ Художник Н.А. Петяева \\ Компьютерный макет: Н.А. Петяева \\ Корректор H.В. Андрианова \\ Формат 60×90 1/8. Гарнитура Open Sans. \\ Уч.-изд. л. 2,0. 1,5 Мб. \\ Изд. № 2528. \\ Национальный исследовательский университет \\ «Высшая Школа экономики» \\ 101000, Москва, ул. Мясницкая, 20, \\ тел.: 8 (495) 772-95-90 доб. 15285
}


